Notes

\title{
CONSTITUTIONAL CROSSROADS: RECONCILING THE TWENTY-FIRST AMENDMENT AND THE COMMERCE CLAUSE TO EVALUATE STATE REGULATION OF INTERSTATE COMMERCE IN ALCOHOLIC BEVERAGES
}

\author{
DUNCAN BAIRD DOUGLASS
}

\begin{abstract}
INTRODUCTION
Trying to purchase a highly rated, limited-production wine ${ }^{1}$ from a local wine retailer can be a fruitless endeavor. In most states, wine retailers are permitted to purchase stock only from a state-licensed wholesaler. If a licensed wholesaler does not carry the particular label a customer desires, the customer will find it difficult or impossible even to special order the wine through a local retailer. Growth in mail-order and electronic commerce, however, has provided new channels through which consumers and producers or retailers can reach each other. The wine industry, particularly small wineries and specialty wine retailers, has made swift use of these burgeoning avenues of commerce. Many wineries and wine retailers permit customers to order coveted bottles of wine over the Internet through their websites. Some oenophiles may be concerned that wines purchased through mail-order or over the Internet will suffer poor travel or storage conditions in the hands of common carriers during the necessary shipping. A Florida resident who purchases wine from an out-of-

1. While the analysis and arguments presented in this Note apply equally to all types of alcoholic beverages, the rapid growth in small wineries, the increased access consumers have to the wines produced by small wineries through mail-order and the Internet, and the growing popularity of limited-production wines make this segment of the liquor industry a particularly strong case study for examining the intersection of old interpretations of the Twenty-first Amendment, modern avenues of interstate commerce, and state liquor laws.
\end{abstract}


state producer or retailer, however, should be far more concerned about avoiding a prison sentence. Florida is one of a number of states that have made it a felony for out-of-state sellers to ship alcoholic beverages to unlicensed residents and for unlicensed residents to receive alcoholic beverages shipped by out-of-state sellers. ${ }^{2}$ Thirty states outlaw the direct shipment of alcoholic beverages, ${ }^{3}$ six of these states make it a felony. ${ }^{4}$

The Twenty-first Amendment is known best for what it accomplished in its first section, repealing the Eighteenth Amendment and ending national Prohibition. ${ }^{5}$ Section two of the Amendment, however, has been much more important and controversial. Without section two, ratification of the Twenty-first Amendment in 1933 would have simply and clearly returned commerce in alcoholic beverages to its pre-Prohibition, unfettered status. Instead, section two of the Amendment prohibits the transportation or importation of alcoholic beverages in violation of state law. ${ }^{6}$ This peculiar constitutional provi-

2. See Fla. StAT. ANN. $§ \S 561.54,562.23$ (West 1999). Section 561.54 criminalizes direct shipment of alcoholic beverages from a location outside of the state of Florida to an unlicensed person in the state and makes repeat offenses a felony. Section 562.23 makes all parties who conspire to do an act which violates any provision of the state alcoholic beverage law, including section 561.54, guilty of a crime of the same degree as the section of the beverage code violated. Thus, an individual in the state of Florida who places an order to have wine shipped directly from an out-of-state location to that person's home may be guilty of conspiring to violate section 561.54, the second violation of which is a third-degree felony.

3. See Ron Eckstein, Grapes of Wrath: Vintners Draw E-Commerce Lobby into a Fight Over Online Wine Sales by Warning that Pending Bill Portends Wider Internet Regulation, LEGAL TIMES, Dec. 6, 1999, at 1. State laws proscribing direct shipment of alcoholic beverages generally prohibit one or both of the following activities: 1) the shipment of alcoholic beverages generally, or wine specifically, from any out-of-state producer, retailer, or other person for delivery to any unlicensed person in the state, or 2) the importation of alcoholic beverages into the state by an unlicensed resident, although some states permit in-person transportation of limited quantities of alcoholic beverages into the state. See infra notes 134-136 and accompanying text.

4. Florida, Indiana, Kentucky, Maryland, North Carolina, and Tennessee have enacted felony direct-shipment laws. See infra note 136.

5. The Eighteenth Amendment, added to the Constitution in 1919, substantively provides: "After one year from the ratification of this article the manufacture, sale, or transportation of intoxicating liquors within, the importation thereof into, or the exportation thereof from the United States and all territory subject to the jurisdiction thereof for beverage purposes is hereby prohibited." U.S. CONST. amend. XVIII, § 1, repealed by U.S. CONST. amend. XXI. Section one of the Twenty-first Amendment, ratified in 1933, provides that "[t]he eighteenth article of amendment to the Constitution of the United States is hereby repealed." U.S. CONST. amend. XXI, § 1 .

6. The text of section two of the Twenty-first Amendment provides: "The transportation or importation into any State, Territory, or possession of the United States for delivery or use therein of intoxicating liquors, in violation of the laws thereof, is hereby prohibited." U.S. CONST. amend. XXI, $\$ 2$. 
sion, which seems to afford explicit constitutional protection to state regulation of trade in alcoholic beverages, led Laurence Tribe to note sardonically that carrying an alcoholic beverage across a state line in violation of the state's liquor laws is one of only two ways that a private individual, not acting under color of state law, can violate the Constitution; the other way is to enslave a person.

Following its ratification, states were quick to rely on the Twenty-first Amendment in establishing a three-tiered system to control the importation and distribution of alcoholic beverages. ${ }^{8}$ Under a three-tiered distribution system, producers of alcoholic beverages are permitted to sell only to state-licensed wholesalers, who in turn may sell only to state-licensed retailers, who then sell to consumers. ${ }^{9}$ States justified the three-tiered distribution system as a way to prevent organized crime-which had run illegal liquor empires during Prohibition-from dominating the legalized liquor industry. ${ }^{10}$ By making the direct sale from producers and wholesalers to consumers illegal and by precluding investment in more than one tier of the distribution system, states were able to prevent organized crime from dominating the industry. ${ }^{11}$ The highly-regulated three-tiered system had virtually no detrimental effect on interstate commerce in alcoholic beverages during the post-Prohibition era, when competition among the many wholesalers was abundant and there were few producers of alcoholic beverages. Few products and many wholesalers competing to distribute those products meant that the limited varieties of alcoholic beverages were widely available. In fact, by the mid-1960s there were more than 10,000 independent wholesalers engaged in the local distribution of liquor. ${ }^{12}$ But over the past forty years the balance has shifted. The alcoholic beverage wholesaling industry has substantially consoli-

7. See Laurence H. Tribe, How to Violate the Constitution Without Really Trying: Lessons from the Repeal of Prohibition to the Balanced Budget Amendment, 12 CONST. COMMENT. 217, 220 (1995) ("[T]here are two ways, and two ways only, in which an ordinary private citizen, acting under her own steam and under color of no law, can violate the United States Constitution. One is to enslave somebody .... The other is to bring a bottle of beer, wine, or bourbon into a State in violation of its beverage control laws.").

8. See Alix M. Freedman \& John R. Emshwiller, Vintage System: Big Liquor Wholesaler Finds Change Stalking Its Very Private World, WALL ST. J., Oct. 4, 1999, at A1.

9. See The Wine Wars, WINE SPECTATOR (visited Feb. 16, 2000) <http://www. winespectator.com/Wine/Spectator/Feature/shippingintro.html> (on file with the Duke Law Journal).

10. See Freedman \& Emshwiller, supra note 8, at A1.

11. See id.

12. See id. 
dated, and the number of alcoholic beverage producers has risen dramatically, changing the commercial landscape of liquor distribution and overloading the states' three-tiered distribution systems. ${ }^{13}$

Of the three classes of alcoholic beverages-liquor, beer, and wine-most of the demand for liquor and beer today is satisfied by a few nationally advertised brands, as it was immediately following ratification of the Twenty-first Amendment. ${ }^{14}$ However, the wine market in the United States today is far different than it was following the end of Prohibition. The number of domestic wineries grew from 375 in 1963 to more than 2,000 in 1999, while the number of wholesalers fell from 10,900 in 1963 to 300 in $1999 .{ }^{15}$

Massive growth in the number of wine producers and rapid consolidation of wholesalers have severely hampered the abilities of wineries to get their products to state markets and of consumers to purchase the alcoholic beverages they desire. A recent survey of the members of the Wine Institute revealed that $37 \%$ of vintners are excluded from selling their wines in at least some states because they cannot find a wholesaler who is willing to distribute their product. ${ }^{16}$ The only avenue available to consumers who live in states where certain desired wines are unavailable is to purchase those wines from out-of-state retailers or directly from the wineries. If the state prohibits the direct shipment of wines, consumers simply cannot purchase wines that are not distributed through their state's three-tiered distribution system. ${ }^{17}$ In essence, by enforcing the three-tiered system of liquor distribution and by prohibiting direct shipment from producers and out-of-state retailers to consumers, states exclude these wineries from their markets. Such state-enforced economic exclusionism is the very thing the Commerce Clause was intended to prevent. Section two of the Twenty-first Amendment, however, has created confusion

13. See infra note 15 and accompanying text.

14. See R. W. Apple, Jr., Zinfandel by Mail? Well, Yes and No; Strict Laws Get Stricter, N.Y. TIMES, May 19, 1999, at F1.

15. See 145 Cong. ReC. H6862 (daily ed. Aug. 3, 1999) (statement of Rep. Thompson) (presenting factual support for the argument that small wine producers face increasing competition and difficulty in gaining acceptance by wholesalers, and thus need to use other avenues to sell their products to consumers).

16. See Freedman \& Emshwiller, supra note 8, at A1 (citing a Wine Institute survey).

17. See, e.g., Tom Campbell, Wine-Shipment Law Challenged: Individuals, Wineries Are Suing ABC Board, RICHMOND TIMES-DisPATCH, Nov. 18, 1999, at B1 (detailing the experience of a Virginia resident who tried twice to order wines from other states by mail and was refused in both attempts by the wineries, which informed the consumer that her state has made it a crime to ship wine to a resident from another state or to receive such a shipment). 
about the extent to which the Commerce Clause applies to this special commercial article, wine.

Part I of this Note reviews the dormant Commerce Clause as it stands in current Supreme Court jurisprudence and its unique application in the context of state laws restricting direct shipment of alcoholic beverages. Part II analyzes the plain meaning and legislative history of the Twenty-first Amendment, and examines the extent to which the Amendment might have created a dormant Commerce Clause exception for state laws regulating the liquor trade. Part III considers the Supreme Court's evolving balancing test for cases where the Twenty-first Amendment and the Commerce Clause intersect, and how lower federal courts have applied this test in recent challenges to state anti-direct-shipment laws. Part IV classifies state laws restricting direct shipment and evaluates each category under the Supreme Court's Commerce Clause/Twenty-first Amendment balancing test. Part V looks at recent congressional involvement in the direct-shipment debate, with a focus on the arguments the states have propounded in seeking federal support for their anti-directshipment laws. Finally, Part VI presents a simple resolution to this increasingly complex debate-a solution that will permit states to protect their core interests under the Twenty-first Amendment without erecting unnecessary barriers to interstate commerce in alcoholic beverages.

\section{The Commerce Clause and State Regulation of Direct SHIPMENT}

The authority of states to enforce their three-tiered distribution systems and to pass broad legislation otherwise regulating the importation and distribution of alcoholic beverages within their borders has been challenged only rarely since the Twenty-first Amendment was ratified in 1933. The recent expansion of the wine industry, along with the growing power of small wine producers and specialty wine retailers to reach consumers through electronic commerce and direct mail, however, have sparked a flurry of debate over the scope of the Amendment that ended Prohibition and the limits the Commerce Clause imposes on states' powers to regulate commerce. 


\section{A. The Dormant Commerce Clause}

The Commerce Clause grants to Congress the power " $[\mathrm{t}] \mathrm{o}$ regulate Commerce... among the several States." ${ }^{18}$ Although the text of the Commerce Clause speaks only of Congress's affirmative powers, "the [Supreme] Court long has recognized that it also limits the power of the States to erect barriers against interstate trade."19 This negative implication of the Commerce Clause is known as the dormant Commerce Clause. ${ }^{20}$ While sometimes criticized as an unwarranted judicial expansion of Congress's expressly delegated Commerce Clause powers, the dormant Commerce Clause has been firmly rooted in our constitutional law for almost two hundred years. ${ }^{21}$ In 1945, Justice Robert Jackson succinctly justified the dormant Commerce Clause, declaring that the very purpose of the Commerce Clause in our Constitution is to ensure "that every farmer and every craftsman shall be encouraged to produce by the certainty that he will have free access to every market in the Nation, that no home embargoes will withhold his exports, and no foreign state will by customs duties or regulations exclude them." 22

The Supreme Court has developed a two-tiered approach to analyzing state regulations that affect interstate commerce, testing state laws that discriminate against interstate commerce more strictly than those that merely burden interstate commerce..$^{23}$ If a state law burdens, but does not discriminate against, interstate commerce, the Court applies a balancing test, weighing "the nature of the local interest involved, and... whether it could be promoted as well with a lesser impact on interstate activities." ${ }^{24}$ A non-discriminatory state

\footnotetext{
18. U.S. CONST., art. I, § 8, cl. 3 .

19. Lewis v. BT Inv. Managers, Inc., 447 U.S. 27, 35 (1980).

20. See, e.g., Oklahoma Tax Comm'n v. Jefferson Lines, Inc., 514 U.S. 175, 179 (1995) (referring to the negative implication of the Commerce Clause as the "dormant Commerce Clause"); Quill Corp. v. North Dakota, 504 U.S. 298, 309 (1992) (same).

21. See ERWIN CHEMERINSKy, CONSTITUTIONAL LAW: PrinciPles AND POlicies 311-12 (1997) (tracing the birth of the dormant Commerce Clause to Chief Justice John Marshall's opinion in Gibbons v. Ogden, 22 U.S. (9 Wheat.) 1 (1824), in which Marshall implied that Congress's Commerce Clause power to regulate trade between the states is exclusive, except where states act in valid exercise of their police powers).

22. H.P. Hood \& Sons, Inc. v. DuMond, 336 U.S. 525, 539 (1949).

23. Under the Commerce Clause, "discrimination" means "differential treatment of instate and out-of-state economic interests that benefits the former and burdens the latter." Oregon Waste Sys., Inc. v. Department of Envtl. Quality, 511 U.S. 93, 99 (1994).

24. Pike v. Bruce Church, Inc. 397 U.S. 137, 142 (1970); see also Southern Pac. Co. v. Arizona, 325 U.S. 761, 770-71 (1945) (holding that a state regulation that affects interstate com-
} 
law violates the dormant Commerce Clause only if "the burden imposed on [interstate] commerce is clearly excessive in relation to the putative local benefits." ${ }^{25}$ As the Court stated in Lewis v. BT Investment Managers, Inc., "legislation that visits its effects equally upon both interstate and local business may survive constitutional scrutiny if it is narrowly drawn." 27

In contrast, a state law that discriminates against interstate commerce, favoring local business, "is per se invalid, save in a narrow class of cases in which the municipality can demonstrate, under rigorous scrutiny, that it has no other means to advance a legitimate local interest. ${ }^{, 28}$ In other words, a state law that discriminates against interstate commerce is unconstitutional unless the state can "justify it both in terms of the local benefits flowing from the statute and the unavailability of nondiscriminatory alternatives adequate to preserve the local interests at stake. ${ }^{29}$ State and local laws are deemed discriminatory, and fall into this more stringent tier of dormant Commerce Clause analysis, if they facially discriminate against interstate commerce or if they are facially neutral but have the purpose or effect of disfavoring out-of-state businesses. ${ }^{30}$ For example, in $C \& A C a r$ -

merce will survive dormant Commerce Clause scrutiny only if the regulation is rationally related to a legitimate state objective and the burden the regulation places on interstate commerce is outweighed by the state interest in enforcing the regulation).

25. Pike, 397 U.S. at 142.

26. 447 U.S. 27 (1980).

27. Id. at 36 .

28. C \& A Carbone, Inc. v. Town of Clarkstown, 511 U.S. 383, 392 (1994); see also Hughes v. Oklahoma, 441 U.S. 322, 337 (1979) ("At a minimum such facial discrimination invokes the strictest scrutiny of any purported legitimate local purpose and of the absence of nondiscriminatory alternatives."); City of Philadelphia v. New Jersey, 437 U.S. 617, 624 (1978) ("[W]here simple economic protectionism is effected by state legislation, a virtually per se rule of invalidity has been erected.").

29. Hunt v. Washington State Apple Adver. Comm'n, 432 U.S. 333, 353 (1977); see also City of Philadelphia, 437 U.S. at 626-27 (declaring that no matter how important the state's objective, "it may not be accomplished by discriminating against articles of commerce coming from outside the State unless there is some reason, apart from their origin, to treat them differently").

30. The Supreme Court has consistently invalidated state laws that facially discriminate against interstate commerce. See, e.g., New Energy Co. v. Limbach, 486 U.S. 269, 274-78 (1988) (finding unconstitutional an Ohio statute that gave a tax credit to fuel dealers for selling ethanol produced in Ohio but no tax credit for sales of ethanol produced in another state); Lewis v. BT Inv. Managers, Inc., 447 U.S. 27, $42-44$ (1980) (striking down a Florida law that prevented outof-state banks from operating investment advisory businesses in the state); Baldwin v. G.A.F. Seelig, Inc., 294 U.S. 511, 526-28 (1935) (declaring that a New York milk price control law, which prevented milk produced out-of-state from being sold at a lower price than milk produced in-state, violated the Commerce Clause). The Court has also vigorously attacked facially neutral but effectively discriminatory state laws. See, e.g., Hunt, 432 U.S. at 352 (declaring un- 
bone, Inc. v. Town of Clarkstown, ${ }^{31}$ the Supreme Court held that a facially neutral city ordinance requiring all nonhazardous solid waste to be deposited at an approved transfer station before leaving the municipality had a discriminatory effect on interstate commerce, because waste processing plants could not ship solid waste themselves but instead had to pay a fee to have the state-approved transfer station ship their waste. ${ }^{32}$ The Court found that the ordinance increased the costs for out-of-state interests operating in the town to dispose of their solid wastes by requiring them to use the favored local processor and also deprived out-of-state waste processing businesses access to a local market. ${ }^{33}$ The town's argument that the law did not discriminate against interstate commerce because its effects weighed evenly upon in-state and out-of-state businesses was rejected because "[t]he ordinance is no less discriminatory because in-state or in-town processors are also covered by the prohibition." ${ }^{34}$ Thus, the fact that a law discriminating against interstate commerce also discriminates against some in-state economic interests will not save it from strict scrutiny under the Court's dormant Commerce Clause analysis.

\section{B. State Liquor Regulations and the Dormant Commerce Clause}

State laws that restrict or prohibit direct shipments of alcoholic beverages seem to be prototypical examples of laws that run afoul of the dormant Commerce Clause. Many of these laws discriminate facially against out-of-state producers and retailers. Even those state laws proscribing direct shipment that do not facially discriminate against interstate commerce have a disparate impact on out-of-state producers and retailers, and therefore are discriminatory in effect. ${ }^{35}$ State anti-direct-shipment laws prevent out-of-state producers and re-

constitutional a North Carolina law that prohibited apples sold in the state from bearing any grade other than a grade prescribed by the federal grading scheme because of the law's discriminatory effect on apples from the state of Washington, which were subjected to a more rigorous grading system); Dean Milk Co. v. City of Madison, 340 U.S. 349, 356 (1951) (striking down a city ordinance requiring that milk be pasteurized within five miles of the city square because, although the ordinance no more discriminated against out-of-state milk than it did milk pasteurized in the state but outside the five-mile zone, the law placed "a discriminatory burden on interstate commerce [that] would invite a multiplication of preferential trade areas destructive of the very purpose of the Commerce Clause").

31. 511 U.S. 383 (1994).

32. See id. at 387-89.

33. See id. at 389-91.

34. Id. at 391.

35. See infra notes 134-36 and accompanying text. 
tailers of alcoholic beverages from transacting business with in-state consumers. The Supreme Court has been relentless in enforcing its edict from Baldwin v. G.A.F. Seelig, Inc. ${ }^{36}$ that "one state in its dealings with another state may not place itself in a position of economic isolation. ${ }^{, 37}$ For example, the Court has used the dormant Commerce Clause to invalidate state laws requiring trucks to use a certain type of mudflap, ${ }^{38}$ limiting the length of railroad trains ${ }^{39}$ and tractor trailers, ${ }^{40}$ requiring that apples not bear another state's grading labels, ${ }^{41}$ and requiring interstate shippers to have state licenses. ${ }^{42}$ Given these and a multitude of other cases applying the Court's well-established dormant Commerce Clause analysis, examining state laws restricting the direct shipment of alcoholic beverages to consumers would seem to be a straightforward exercise. Applying the test from $C \& A$ Carbone ${ }^{43}$ these laws should be per se invalid unless the state can prove they are the least discriminatory means of advancing a legitimate state interest. ${ }^{44}$

Typically when a state law that discriminates against interstate commerce is challenged, dormant Commerce Clause analysis is conclusive. In analyzing the validity of state anti-direct-shipment laws, however, the dormant Commerce Clause is not the only constitutional provision that must be consulted: the Twenty-first Amendment also must be considered.

When states regulate the liquor trade, the Twenty-first Amendment and the dormant Commerce Clause swirl together, creating a

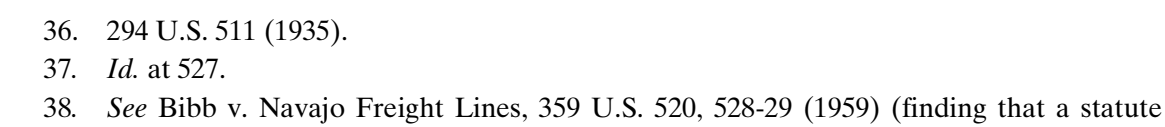
requiring all trucks traveling on the state's roads to use curved mudflaps, while not discriminatory, placed an unconstitutional burden on interstate commerce).

39. See Southern Pac. Co. v. Arizona, 325 U.S. 761, 781-82 (1945) (holding unconstitutional a state law which limited the maximum length of passenger and freight trains because the law's dubious safety benefits were outweighed by the burden it placed on interstate commerce).

40. See Kassel v. Consolidated Freightways Corp., 450 U.S. 662, 671-73 (1981) (finding that the state provided no persuasive evidence that the prohibited sixty-five-foot double trailers were any less safe than trailers the state permitted to operate on its roadways).

41. See Hunt v. Washington State Apple Adver. Comm'n, 432 U.S. 333, 353-54 (1977) (finding unconstitutional a state law that prevented apples sold in the state from bearing any grade other than a standard U.S. grade because the law discriminated against apple growers in states with more sophisticated and expensive apple grading systems).

42. See Buck v. Kuykendall, 267 U.S. 307, 316 (1925) (holding unconstitutional a state law which required common carriers using public highways to obtain a license from the state).

43. See supra note 28 and accompanying text.

44. See supra notes 28-34 and accompanying text. 
turbid mixture that makes determining the constitutional validity of such state laws difficult. Ironically, the non-textual dormant Commerce Clause is the clearer of the two components in this constitutional concoction; interpreting the Twenty-first Amendment has proven exceedingly difficult.

\section{THE TWENTY-FIRST AMENDMENT}

The Twenty-first Amendment is comprised of three sections: section one simply repealed the Eighteenth Amendment; ${ }^{45}$ section three set a time limit of seven years for the states to ratify the Amendment; ${ }^{46}$ section two provides that " $[\mathrm{t}]$ he transportation or importation into any State, Territory, or possession of the United States for delivery or use therein of intoxicating liquors, in violation of the laws thereof, is hereby prohibited." ${ }^{47}$ Judges and commentators have debated whether section two completely trumps the dormant Commerce Clause, granting to states the authority to regulate interstate commerce in alcoholic beverages unfettered by the constitutional constraints of the Commerce Clause. ${ }^{48}$ As in statutory construction, ascertaining the true scope of section two must begin with an analysis of the plain meaning of its text, followed by due consideration for the intent of the Congress that crafted it. ${ }^{49}$

45. "The eighteenth article of amendment to the Constitution of the United States is hereby repealed." U.S. CONST. amend. XXI, § 1.

46. "This article shall be inoperative unless it shall have been ratified as an amendment to the Constitution by conventions in the several States, as provided in the Constitution, within seven years from the date of the submission hereof to the States by the Congress." U.S. CONST. amend. XXI, § 3. After the debacle surrounding the ratification of the Twenty-seventh Amendment, which was presented to the states with no timetable for ratification and subsequently took over 200 years to garner the requisite number of state approvals, such a time limit seems, especially in comparison, uncontroversial. See Tribe, supra note 7, at 218.

47. U.S. CONST. amend. XXI, § 2 .

48. See, e.g., John E. NowaK \& Robert D. Rotunda, Constitutional Law §4.9, at 163 n.33, § 8.8, at 300-01 (West 5th ed. 1995) (discussing generally the interplay between the Twenty-first Amendment and the Commerce Clause); Vijay Shanker, Note, Alcohol Direct Shipment Laws, The Commerce Clause, and the Twenty-first Amendment, 85 VA. L. REV. 353, 372-83 (1999) (remarking on the historical development of Twenty-first Amendment and Commerce Clause jurisprudence).

49. Cf. City of Boerne v. Flores, 521 U.S. 507, 519-24 (1997) (looking first at the text and design of the Fourteenth Amendment and then to its legislative history in ascertaining the Amendment's meaning); Powell v. McCormack, 395 U.S. 486, 519-48 (1969) (examining the text and the history of the Qualifications Clause to determine the scope of authority that the Clause grants to Congress to judge its members). 


\section{A. Plain Meaning}

Analysis of the meaning of a constitutional provision must begin with an examination of its text. ${ }^{50}$ However, interpreting the meaning of the language employed in a constitutional amendment depends not simply on the naked meaning of its words, but also on the context. ${ }^{51}$ The difficulty in applying these plain meaning principles of construction to section two of the Twenty-first Amendment is that the text of the Amendment, read independently and in the context of other constitutional provisions, can be interpreted very broadly or very narrowly with equal justification.

At one extreme, section two can be read as implicitly granting the states a complete exemption from the operation of other constitutional provisions in the regulation of trade in alcoholic beverages. States could, under this interpretation, impose large importation taxes on all out-of-state alcoholic beverages while exempting in-state producers from any taxes whatsoever. Such a facially discriminatory law would be protected from invalidation under the dormant Commerce Clause by this broad interpretation. Yet, even in its most liberal reading of section two, the Supreme Court has never suggested that states have such unrestricted authority in regulating alcoholic beverages. $^{52}$

50. See Holmes v. Jennison, 39 U.S. (14 Pet.) 540, 570-71 (1840) ("In expounding the Constitution of the United States, every word must have its due force, and appropriate meaning ....”); Gibbons v. Ogden, 22 U.S. (9 Wheat.) 1, 189 (1824) ("We know of no rule for construing the extent of such powers, other than is given by the language of the instrument which confers them, taken in connexion [sic] with the purposes for which they were conferred."); Martin v. Hunter's Lessee, 14 U.S. (1 Wheat.) 304, 338-39 (1816) ("If the text be clear and distinct, no restriction upon its plain and obvious import ought to be admitted, unless the inference be irresistible.").

51. See, e.g., United States v. Balsys, 524 U.S. 666, 673 (1998) (discounting the respondent's purely textual analysis of the Fifth Amendment because "the argument overlooks the cardinal rule to construe provisions in context"); Youngstown Sheet \& Tube Co. v. Sawyer, 343 U.S. 579, 645 (Jackson, J., concurring) (stating that the provisions of the Constitution cannot be read in isolation but rather must be read in context).

52. See, e.g., Larkin v. Grendel's Den, Inc., 459 U.S. 116, 126-27 (1982) (finding that the Twenty-first Amendment does not exclude state regulation of alcoholic beverages from the Establishment Clause); Craig v. Boren, 429 U.S. 190, 209 (1976) (pronouncing that states cannot regulate the liquor industry in a manner that violates the Equal Protection Clause); Wisconsin v. Constantineau, 400 U.S. 433, 436 (1971) (declaring that the Twenty-first Amendment did not exempt state liquor regulations from Fourteenth Amendment due process requirements); Department of Revenue v. James B. Beam Distilling Co., 377 U.S. 341, 344 (1964) (declaring that "[t]his Court has never so much as intimated that the Twenty-first Amendment has operated to permit [the type of discriminatory taxation that] the Export-Import Clause precisely and explicitly forbids"). 
The plain meaning of section two can also be read very narrowly. On its face the language in section two grants no new powers to the states to regulate alcoholic beverages but merely adds the explicit support of the Constitution to state laws regulating the importation and transportation of alcoholic beverages-laws that formerly were preempted by the Eighteenth Amendment. Thus section two can be interpreted as presupposing that the state laws it protects do not violate the dormant Commerce Clause. After all, section two only prohibits "transportation or importation into any State . . f for delivery or use therein of intoxicating liquors, in violation of the laws thereof.",53 Arguably, nothing in the text of section two overtly expands the powers of the states to regulate alcoholic beverages beyond the authority they would otherwise have.

Having derived no singularly correct meaning from the text of section two, one turns to the legislative history to determine what the enacting Congress intended. Notwithstanding Justice Powell's admonition that the Supreme Court should be hesitant to look to the legislative history of the Twenty-first Amendment for help in ascertaining its proper meaning, ${ }^{54}$ the Court has regularly acknowledged the validity of consulting the legislative history of constitutional provisions when textual analysis is not determinative. ${ }^{55}$

\section{B. Congressional History}

Even textualists like Justices Scalia and Thomas acknowledge the value of examining ratification debates to interpret provisions of the

\footnotetext{
53. U.S. CONST. amend. XXI, cl. 2 (emphasis added).

54. See California Retail Liquor Dealers Ass'n v. Midcal Aluminum, Inc., 445 U.S. 97, 107 n.10 (1980).

55. See, e.g., Balsys, 524 U.S. at 674 (relying exclusively on the text and context of the Fifth Amendment in determining the scope of the Self-Incrimination Clause "[s]ince there is no helpful legislative history"); Bailey v. United States, 516 U.S. 137, 145 (1995) (declaring that "[w]e consider not only the bare meaning [of the language used in a statute] but also its placement and purpose in the statutory scheme"); Brown v. Garnder, 513 U.S. 115, 118 (1994) ("“[T]he meaning of statutory language, plain or not, depends on context."' (quoting King v. St. Vincent's Hosp., 502 U.S. 215, 221 (1991))); United States v. Classic, 313 U.S. 299, 317-18 (1941) (declaring that " $[\mathrm{t}$ ] decide [the meaning of a constitutional provision] we turn to the words of the Constitution read in their historical setting as revealing the purpose of its framers, and search for admissible meanings of its words which, in the circumstances of their application, will effectuate those purposes"); Weems v. United States, 217 U.S. 349, 368-69 (1910) (looking first at the text and then to historical congressional debate in trying to determine what constitutes "cruel and unusual punishment" within the meaning of the Eighth Amendment).
} 
Constitution. ${ }^{56}$ Because the only clear principle that can be gleaned from the text of the Twenty-first Amendment is that it was intended to end the failed noble experiment of constitutional Prohibition, the Supreme Court has frequently looked beyond the text of section two to its legislative history in its efforts to ascertain the scope of authority that the Twenty-first Amendment conferred on the states. ${ }^{57}$

The legislative history of the Twenty-first Amendment supports three distinct interpretations of section two. The most restrictive interpretation supported is that section two did not exempt the states from any other provisions of the Constitution, but merely returned authority to regulate commerce in intoxicating liquors to the states. The second interpretation of section two, revealed only in its legislative history, is that it was included in the Amendment solely to ensure that states wanting to remain dry after repeal of the Eighteenth Amendment would have the power to enact laws to do so. The final and most expansive interpretation that can be gleaned from the legislative history of section two is that it entirely exempted state regulation of commerce in alcoholic beverages from the limitations of the Commerce Clause, which otherwise would prevent states from discriminating against such interstate commerce. The debates over proposed versions of the Amendment reveal that each of these views was held by some members of Congress who ultimately supported the inclusion of section two in the Twenty-first Amendment.

The Twenty-first Amendment garnered the requisite two-thirds vote in each house of Congress without raising much substantive de-

56. Justice Scalia and Justice Thomas have often looked to the Framers or to ratification debates to construe provisions of the Constitution. See, e.g., Printz v. United States, 521 U.S. 898, 909-25 (1997) (Scalia, J.); City of Boerne v. Flores, 521 U.S. 507, 537 (1997) (Scalia, J., concurring in part); Plaut v. Spendthrift Farm, Inc., 514 U.S. 211, 219-25 (1995) (Scalia, J.); Morrison v. Olson, 487 U.S. 654, 697-99 (Scalia, J., dissenting); U.S. Term Limits, Inc. v. Thornton, 514 U.S. 779, 845-926 (1995) (Thomas, J., dissenting). Professor Eskridge has identified this irony. See William N. Eskridge, Jr., Should the Supreme Court Read The Federalist but Not Statutory Legislative History?, 66 GEO. WASH. L. REV. 1301, 1301 (noting that even textualists Scalia and Thomas freely look to the history of constitutional provisions when interpreting their meaning, even though these Supreme Court Justices are reluctant to consider legislative history when construing statutes).

57. See 324 Liquor Corp. v. Duffy, 479 U.S. 335, 346-47 n.10 (1987) (reviewing the legislative history of section two of the Twenty-first Amendment and disagreeing with the dissent's position that congressional intent undercuts the Court's holding); Bacchus Imports, Ltd. v. Dias, 468 U.S. 263, 274-75 (1984) (looking at the congressional history of the Twenty-first Amendment for guidance in interpreting section two); Department of Revenue v. James B. Beam Distilling Co., 377 U.S. 341, 345-46 (1964) (pointing to both the language and the history of the Twenty-first Amendment as support for holding that state liquor regulations are not exempt from the Export-Import Clause). 
bate, probably because most members of Congress saw section one, the simple repeal of constitutional Prohibition, as the bulk of the Amendment's purpose and substance.$^{58}$ It seems that sections two and three of the Amendment were seen as being primarily procedural sections, necessary to support and implement section one. What substantive debate there was regarding the formulation of the Amendment focused principally on two subjects: whether the text should explicitly prohibit saloons $^{59}$ and the means of ratifying the Amendment. The meaning of the provision that became section two of the Twenty-first Amendment was subjected to limited scrutiny.

1. Debate on Section Two of Senate Joint Resolution 211. Whether section two would be included in the version of the Resolution presented to the states for ratification was uncertain until the final votes were cast. Senator Blaine, speaking on behalf of the Senate Judiciary Committee, defended the inclusion of section two in the proposed constitutional amendment by stating that the Committee included it "to assure the so-called dry States against the importation of intoxicating liquor into those States." presentation of Senate Joint Resolution 211, the original bill that became the Twenty-first Amendment, Senator Blaine reiterated several times that the purpose of section two was to guarantee protection to states that might choose to remain dry, ${ }^{61}$ and concluded by saying, "I am willing to grant to the dry States full measure of protection, and thus prohibit the wet States from interfering in their internal affairs respecting the control of intoxicating liquors." ${ }^{, 62}$ These

58. See generally supra notes 59-72. In the Senate, more debate was devoted to a dispute over whether the Amendment should require ratification by state legislatures or by state conventions than was devoted to defining the meaning of section two of the proposal. See 76 CONG. REC. 4148-69 (1933) (debating a proposed amendment to Senate Joint Resolution 211 that would substitute the requirement of ratification by state "conventions" for the requirement of ratification by state "legislatures"). Senate Joint Resolution 211 passed the Senate by a vote of 63-23, garnering the necessary two-thirds vote for a proposed constitutional amendment. See id. at 4231 (recording the Senate's roll call vote on Resolution 211). Senate Joint Resolution 211 passed the House by a vote of 289-121, garnering the necessary two-thirds vote for a proposed constitutional amendment. See id. at 4516 (recording the House of Representatives' roll call vote on Resolution 211).

59. See id. at 4215-30 (detailing Senate debate on the saloon issue); id. at 4510-16, 4518-22, 4526-29 (detailing House debate on the saloon issue).

60. 76 CONG. REC. 4141 (1933) (statement of Sen. Blaine).

61. See id. ("The [Senate Judiciary] [C]ommittee felt ... that we could well afford to guarantee to the so-called dry States the protection designed by section two.").

62. Id. 
remarks on behalf of the Judiciary Committee create a reasonable inference that the Committee that crafted section two intended it to serve the limited purpose of allowing states to remain dry after the repeal of Prohibition.

Not all Senators, however, agreed with the Judiciary Committee's interpretation. Even Senator Blaine himself, no longer speaking on behalf of the Judiciary Committee but defending section two personally, offered a broader interpretation: the section could be interpreted as "restoring to the States ... the right to regulate commerce respecting a single commodity-namely, intoxicating liquor." ${ }^{63}$ At first blush, this language seems to support the argument that section two created a Commerce Clause carve-out, granting states the power to regulate even interstate commerce involving alcoholic beverages. At least one commentator has pointed to Senator Blaine's personal defense of section two as conclusive evidence that it was meant to exempt state regulations of alcoholic beverages from the operation of the Commerce Clause altogether. ${ }^{64}$ A closer look at Senator Blaine's statement, which centered on the word "restoring," reveals at least equal support, however, for the contention that section two merely returned the authority that the Eighteenth Amendment had taken from the states-the use of their police powers to enact alcoholic beverage regulations subject to the limits of the Commerce Clause.

Debate among other senators provides no clearer guidance on the proper role of section two in the Twenty-first Amendment. The discussion that ensued when Senator Robinson proposed to strike section two from Joint Resolution 211 demonstrates the range of views among senators on the meaning of that section. Senator Borah defended section two, arguing "we can[not] afford to strip the amendment of all effort to protect the dry states." then embarked on a lengthy speech in which he described the hapless plight of those states that, absent section two, would choose to remain dry but would be unable to fend off those who inevitably would violate their efforts by illegally importing alcohol, extolling the need to include language explicitly supporting states' rights to remain dry in

63. Id. at 4143 .

64. See Richard S. Mandel, Note, Liquor Advertising: Resolving the Clash Between the First and Twenty-First Amendments, 59 N.Y.U. L. REV. 157, 167-68 (1984) (stating that the legislative history of the Twenty-first Amendment "clearly discloses" the Framers' intent to create an exemption for states to regulate commerce in alcoholic beverages unrestricted by the Commerce Clause).

65. 76 CONG. REC. 4170 (1933) (statement of Sen. Borah). 
the proposed amendment. ${ }^{66}$ Senator Wagner seconded Senator Borah's defense of section two, saying that "if the dry States want additional assurance that they will be protected I shall have no objection." ${ }^{67}$ Senator Robinson, acknowledging the weight of Senator Borah's remarks, then recanted his proposal to delete section two from the Resolution, saying that he did not "wish to ask the Senate to put itself in the position of denying any measure of protection to dry territory." ${ }^{, 68}$ This dialogue among senators who supported the inclusion of section two in Senate Joint Resolution 211 suggests that the provision was understood simply as protection for dry states-an effort to enable them to use their police powers to block all importation of intoxicating liquors. Nothing in these remarks suggests that any of these three ultimate supporters of section two believed it would give wet states the authority to regulate commerce in alcoholic beverages in a way that would run afoul of the Commerce Clause.

When Senate Joint Resolution 211, having passed the Senate, was sent to the House for consideration, the brief debate concerning the Resolution focused on the same issues. Representative Robinson summarized the provisions of the Resolution to the other representatives as follows: "Section 1 repeals the eighteenth amendment. Section 2 attempts to protect dry States. Section 3 provides State ratification by the convention method within seven years. It does not say a word against the return of the saloon!" ${ }^{69}$

66. See id. at 4170-71. In his oratory, Senator Borah disparagingly referred to the Supreme Court case of Bowman v. Chicago \& N.W. Ry. Co., 125 U.S. 465 (1888), in which the Court held that states could not use a licensing requirement, which required common carriers to obtain a state license to bring intoxicating liquors into the state, to prevent unlicensed shippers from carrying intoxicating liquors into the state. See id. at 500. Bowman was one of the seminal cases establishing the dormant Commerce Clause. In Bowman, the Court ruled that when Congress has failed to pass legislation touching a matter of interstate commerce, it is presumed that Congress intends the matter to remain unfettered by any legislation or regulation. See id. Senator Borah cited the Bowman case as exemplifying that dry states could not rely on their police powers to protect against the importation of liquor absent express authorization of Congress to do so. See 76 CONG. REC. 4171 (1933) (statement of Sen. Borah). Senator Borah's argument is the closest any member of either house came to asserting affirmatively that section two created a Commerce Clause carve-out for states, allowing them unfettered authority to regulate even interstate transactions involving alcoholic beverages. Nevertheless, Senator Borah asserted that his intention in supporting section two was to create and protect the right of states to remain dry. See id.

67. 76 CONG. REC. 4171 (1933) (statement of Sen. Wagner).

68. Id. (statement of Sen. Robinson).

69. See id. at 4518 (statement of Rep. Robinson). 
2. Consideration of Senate Joint Resolution 202. Shortly before the vote was taken in the Senate on Senate Joint Resolution 211, Senator Glass proposed Senate Joint Resolution 202 as a substitute. Senate Joint Resolution 202 contained a single section which, besides repealing the Eighteenth Amendment, would have outlawed saloons explicitly, prevented importation of alcoholic beverages into dry states, and granted concurrent power of enforcement to Congress and the states. ${ }^{70}$ Senator Fletcher, expressing general approval of Senate Joint Resolution 202 as a viable substitute for Joint Resolution 211, requested that Senator Glass redact the "concurrent power" language because it would create unnecessary confusion. Senator Fletcher argued that since "Congress has power to regulate interstate commerce and to prohibit the movement of wet goods into dry States ... we do not need to express that in a new amendment to the Constitution." " ${ }^{, 1}$ Senator Glass responded that, as he interpreted Senate Joint Resolution 202, "[1]iquors may be shipped across a State in interstate commerce from one wet State to another wet State, but the resolution ... prohibits the shipment of intoxicating liquors into a State whose laws prohibit the manufacture, transportation, and sale of liquors." "72 Thus, Senator Glass and Senator Fletcher agreed that their goal was to support an amendment to the Constitution that would retain in full force Congress's Commerce Clause powers while ensuring that dry states had the authority necessary to prevent illegal shipment of liquor into their territory. ${ }^{73}$

70. See id. at 4211-12 (statement of Sen. Glass). The text of Senate Joint Resolution 202, in relevant part, provided:

Article XVIII of the amendments to this Constitution is hereby repealed. The sale of intoxicating liquors within the United States or any territory subject to the jurisdiction thereof for consumption at the place of sale (commonly known as a saloon), and the transportation of intoxicating liquors into any State, Territory, District, or possession of the United States in which the manufacture, sale, and transportation of intoxicating liquors are prohibited by law, are hereby prohibited. The Congress and the several States, Territories, and possessions shall have concurrent power to enforce this article by appropriate legislation.

Id.

71. 76 CONG. REC. 4219 (1933) (statement of Sen. Fletcher).

72. Id. (statement of Sen. Glass).

73. Besides the brief exchange between Senators Glass and Fletcher, all debate considering Senate Joint Resolution 202 as a substitute for Senate Joint Resolution 211 focused on the explicit anti-saloon provision in Resolution 202, with several senators remarking that they would have no preference for either Resolution if Senator Glass would amend his proposal so that Congress's "concurrent power" did not give it authority to regulate saloons. See id. at 4218-22 (detailing statements by Senators Reed and Barkley conditioning their support of Senator 
Although Senate Joint Resolution 202 ultimately was rejected by a vote of 46-38 as a replacement for Joint Resolution 211, the debate about the differences between the two proposals demonstrates that many supporters of the Twenty-first Amendment perceived section two as simply a measure included to protect dry states. The absence of more substantive debate on the meaning of section two and the relatively few members of Congress who presented their interpretations of that provision during the debate make it difficult to draw further meaningful conclusions from the legislative history. One can legitimately assert, however, that the limited legislative history of section two supports reading that provision narrowly-as an all-ornothing protection for dry states-as much as it supports reading the section broadly-as a complete Commerce Clause exemption for state liquor laws.

The plain meaning of the text and the legislative history, taken together, do not reveal a single, correct interpretation of the effect the Amendment had on state authority to regulate commerce in alcoholic beverages following the repeal of Prohibition. Absent definitive interpretive guidance on the issue from the text or history of the Twenty-first Amendment, the Supreme Court—as the authoritative expositor of the Constitution-has been left the task of disentangling this interpretive thicket.

\section{INTERPLAY BETWEEN THE COMMERCE ClAUSE AND THE TWENTY-FIRST AMENDMENT: EVOLUTION OF INTERPRETIVE JURISPRUDENCE}

Since the Twenty-first Amendment was ratified on December 5, 1933, the Supreme Court has unwaveringly declared that the Amendment does not limit other provisions of the Constitution, except for the Commerce Clause. ${ }^{74}$ Regarding the Commerce Clause, Supreme Court jurisprudence has been much less consistent, evolving from a very broad reading of the Twenty-first Amendment in cases

Glass's amendment on removal of the "concurrent power" language); id. at 4225 (recording a statement by Senator Reed declaring that he would vote for either resolution if the "concurrent power" clause were stricken from Senate Joint Resolution 202). Senator Gore attested that "the purpose of the substitute offered by ... Senator [Glass] is to prevent the return of the saloon." Id. at 4222 (statement of Sen. Gore). As Senator Reed stated, absent language giving Congress and the States concurrent power to regulate saloons in whatever resolution was adopted, "Congress will have no power to provide prohibition enforcement in the separate States, further than the power it now has to regulate interstate commerce." Id. at 4225 (statement of Sen. Reed).

74. See supra note 52 and accompanying text. 
decided immediately following ratification to a much narrower interpretation of the Amendment over the past forty years. In fact, the most recent Supreme Court cases addressing the interplay between the Commerce Clause and the Twenty-first Amendment seem to have all but abandoned the notion, espoused in earlier decisions, that the Twenty-first Amendment absolutely shields state liquor regulations from Commerce Clause scrutiny. Furthermore, lower federal courts, pointing to these recent Supreme Court cases, have confirmed this narrowing interpretation of the Twenty-first Amendment, disagreeing with states' arguments that the Amendment protects liquor laws that affect interstate commerce and finding the laws unconstitutional.

\section{A. Early Supreme Court Interpretation of the Twenty-first Amendment}

The Supreme Court was presented with several cases involving the intersection of the Commerce Clause and the Twenty-first Amendment in the years following ratification. At each opportunity, the Court interpreted the scope of the Twenty-first Amendment broadly, finding that state authority to regulate commerce in intoxicating liquors was entirely free from the restrictions of the dormant Commerce Clause. ${ }^{75}$ For example, in State Board of Equalization v. Young's Market Co., a 1936 decision marking the Supreme Court's first foray into this interpretive bog, the Court said that the Twentyfirst Amendment "confer[s] upon the State the power to forbid all importations which do not comply with the conditions which it prescribes." ${ }^{, 76}$ If the decision in Young's Market left any doubt that the Twenty-first Amendment created a complete Commerce Clause carve-out for states to regulate all aspects of commerce involving alcoholic beverages, only three years later, in Ziffrin, Inc. v. Reeves, the Court affirmed its earlier interpretation by declaring that " $[\mathrm{t}] \mathrm{he}$ Twenty-first Amendment sanctions the right of a State to legislate

75. See, e.g., Ziffrin, Inc. v. Reeves, 308 U.S. 132, 138 (1939) ("Without doubt a State may absolutely prohibit the manufacture of intoxicants, their transportation, sale, or possession, irrespective of where produced or obtained ....."); Indianapolis Brewing Co. v. Liquor Control Comm'n, 305 U.S. 391, 394 (1939) ("Since the Twenty-first Amendment ... the right of a state to prohibit or regulate the importation of intoxicating liquor is not limited by the commerce clause ...."); State Bd. of Equalization v. Young's Market Co., 299 U.S. 59, 61-62 (1936) (upholding broad state authority to regulate the "importation and transportation" of intoxicating liquor in ways that, absent the Twenty-first Amendment, would violate the Commerce Clause).

76. 299 U.S. 59, 62 (1936). 
concerning intoxicating liquors brought from without, unfettered by the Commerce Clause."

Over the past four decades, the Supreme Court has retreated substantially from its early, broad interpretations of the Twenty-first Amendment. The passage of time, and more careful consideration of the substantial role that the dormant Commerce Clause plays in preventing states from engaging in commercial isolationism in an increasingly national economy, led the Court to acknowledge that the dormant Commerce Clause should and does place limits on the ability of the states to regulate commerce in alcoholic beverages.

\section{B. Modern Supreme Court Twenty-first Amendment Jurisprudence}

Despite narrowing its interpretation of the scope of the Twentyfirst Amendment in more recent cases, the Supreme Court has remained hesitant to establish bright-line rules where the Amendment and the Commerce Clause intersect. ${ }^{78}$ The Supreme Court's reluctance to set definitive parameters on the extent to which state laws regulating commerce in alcoholic beverages are protected has led to a series of challenges to such state laws. The Supreme Court's holdings and reasoning in these more recent cases have progressively narrowed the scope of the Amendment, leaving the Amendment's formerly large bite into the Commerce Clause with few, if any, remaining teeth.

1. The Narrowing Scope of the Twenty-first Amendment. The Supreme Court's decision in Hostetter v. Idlewild Bon Voyage Liquor Corp. $^{79}$ gave the first clear and substantial indication that the Commerce Clause could be an effective weapon for battling state laws regulating the trade in alcoholic beverages. In Idlewild, the Court explicitly rejected the logical conclusion from its earlier opinions that the Twenty-first Amendment "has somehow operated to 'repeal' the Commerce Clause wherever regulation of intoxicating liquors is concerned." Instead, the Court declared: "Both the

77. 308 U.S. 132, 138 (1939).

78. In fact, after reviewing its own Twenty-first Amendment jurisprudence, the Supreme Court declared that " $\mathrm{t}$ ]hese decisions demonstrate that there is no bright line between the federal and state powers over liquor." California Retail Liquor Dealers Ass'n v. Midcal Aluminum, Inc., 445 U.S. 97, 110 (1980).

79. 377 U.S. 324 (1964).

80. Id. at $331-32$. 
Twenty-first Amendment and the Commerce Clause are parts of the same Constitution. Like other provisions of the Constitution, each must be considered in the light of the other, and in the context of the issues and interests at stake in any concrete case."

Sixteen years later, in California Retail Liquor Dealers Ass'n v. Midcal Aluminum, Inc., ${ }^{82}$ the Court attempted to clarify Idlewild by distinguishing what would later be referred to as states' "core powers" under the Amendment from other alcoholic beverage regulations. $^{83}$ In Midcal, the Court announced that "[t]he Twenty-first Amendment grants the States virtually complete control over whether to permit importation or sale of liquor and how to structure the liquor distribution system." ${ }^{, 4}$ This statement suggests that Idlewild did not stand for the proposition that every state statute conceivably related to the liquor trade was unfettered by the Commerce Clause. Instead, the Midcal Court's clarification indicates that the only state laws that are free from the normal operation of the Commerce Clause are those pertaining to the decision of whether to be a dry state and, if the decision is made not to be dry, those governing the structure of alcoholic beverage distribution. However, this seemingly clear explanation was muddied somewhat by the Midcal Court's assertions that "[state liquor] controls may be subject to the federal commerce power in appropriate situations" ${ }^{" 85}$ and that reconciling the Twenty-first Amendment and the Commerce Clause requires a "pragmatic effort to harmonize state and federal powers." seemed to be drawing a bright line between state liquor regulations that fall within the core powers of the Twenty-first Amendment, which states could exercise unhindered by the dormant Commerce Clause, and liquor regulations that are subject to Commerce Clause restraints, it complicated the distinction by suggesting that a balancing test should be applied whenever a state liquor regulation-whether or not an exercise of core powers-interferes with interstate commerce. The Court clarified the operation of the core powers distinction and the balancing test it had suggested in Midcal by applying these principles in two cases decided in 1984.

\footnotetext{
81. Id. at 332 .

82. 445 U.S. 97 (1980).

83. See infra Part III.B.3.

84. Midcal, 445 U.S. at 110.

85. Id.

86. Id. at 109 .
} 
2. Balancing the Commerce Clause and the Twenty-first Amendment. In Capital Cities Cable, Inc. v. Crisp, the Court shed some light on how to harmonize state liquor laws enacted under the Twenty-first Amendment with the dormant Commerce Clause by articulating a balancing test to be applied when a state alcoholic beverage regulation conflicts with any federal law. ${ }^{87}$ While Capital Cities involved a conflict between a state restriction on television liquor advertisements and a federal law preempting all state regulation of cable television signals, the Court characterized the issues at stake in the same way it characterizes conflicts between state liquor regulations and the Commerce Clause. ${ }^{88}$ The Capital Cities Court said that where a state law purportedly enacted under the authority of the Twenty-first Amendment collides with a federal law, the conflict should be resolved by determining "whether the interests implicated by [the] state regulation are so closely related to the powers reserved by the Twenty-first Amendment that the regulation may prevail, notwithstanding that its requirements directly conflict with express federal policies." ${ }^{, 9}$ In applying this balancing test, the Capital Cities Court concluded that the state's interest in preventing the advertisment of alcoholic beverages on television was not of sufficient gravity or related closely enough to the central purpose of the Twenty-first Amendment to override the Supremacy Clause. ${ }^{90}$

In the same month that it handed down the Capital Cities opinion, the Supreme Court rendered its most significant decision to date interpreting the interplay between the Twenty-first Amendment and the dormant Commerce Clause, Bacchus Imports, Ltd. v. Dias. ${ }^{91}$ At issue in Bacchus was a Hawaii state liquor tax imposed on all alcoholic beverages except for certain types of brandy and fruit wine produced in Hawaii. ${ }^{92}$ In evaluating the plaintiff's Commerce Clause challenge to the state statute, the Bacchus Court applied the Capital Cities balancing test in a two-step analysis. In the first step, the Court examined the statute under traditional dormant Commerce Clause analysis. ${ }^{93}$ The Court found that the Hawaii liquor tax unjustifiably

\footnotetext{
87. 467 U.S. 714 (1984).

88. See id. at $713-14$.

89. Id. at 714 .

90. See id. at 715-16.

91. 468 U.S. 263 (1984).

92. See id. at 265 .

93. See id. at 268-73. The Court began its analysis by noting that a "cardinal rule of Commerce Clause jurisprudence is that no State, consistent with the Commerce Clause, may impose
} 
discriminated against interstate commerce..$^{44}$ As it would for a case involving an article of commerce like milk ${ }^{95}$ or apples, ${ }^{96}$ the Court then looked to the state to provide a justification sufficient to overcome the standard Commerce Clause presumption that the discriminatory tax was unconstitutional. ${ }^{97}$ The state argued that, because the tax applied to the liquor industry, it was saved by the Twenty-first Amendment. ${ }^{98}$ In the second step of the balancing test analysis, the Court considered whether the Twenty-first Amendment shielded the discriminatory state regulation from invalidation under the Commerce Clause. ${ }^{99}$

The Bacchus Court began its Twenty-first Amendment analysis by reiterating that the expansive interpretation it had given to section two in its earlier decisions had been too broad. ${ }^{100}$ The Court emphasized its understanding that the Twenty-first Amendment "did not entirely remove state regulation of alcoholic beverages from the ambit of the Commerce Clause" industries by erecting barriers to competition." 102 Noting that "the Commerce Clause itself furthers strong federal interests in preventing economic Balkanization," the Court asserted that "[s]tate laws that constitute mere economic protectionism are... not entitled to the same deference as laws enacted to combat the perceived evils of an unrestricted traffic in liquor." ${ }^{103}$ Applying these principles to Hawaii's liquor tax scheme, the Court concluded that the discriminatory tax

a tax which discriminates against interstate commerce." $I d$. at 268 (internal quotation marks omitted).

94. See id. at 273 (rejecting the state's claim that the tax was aimed at promoting local industry rather than discriminating against interstate commerce because a state law necessarily discriminates against interstate commerce whether its intent is to burden out-of-state parties or to favor in-state parties).

95. See Dean Milk Co. v. City of Madison, 340 U.S. 349, 356 (1951) (finding unconstitutional a state law discriminating against milk imported from other states).

96. See Hunt v. Washington State Apple Adver. Comm'n, 432 U.S. 333, 348-54 (1977) (striking down a North Carolina law that discriminated against apple producers from the State of Washington).

97. See Bacchus, 468 U.S. at 274 (addressing the state's argument that even if the liquor tax does contravene the Commerce Clause, it was a valid exercise of state power under the Twentyfirst Amendment).

98. See id.

99. See id.

100. See id. at 274-76.

101. Id. at 275 .

102. Id. at 276 .

103. Id. 
could not be saved by the Twenty-first Amendment because it "was [not] designed to promote temperance or carry out any other purpose of the Twenty-first Amendment." sufficiently related to the exercise of core powers under the Twentyfirst Amendment to be saved from the normal operation of the Commerce Clause. The Bacchus decision remains the clearest authoritative instruction for harmonizing the dormant Commerce Clause with the Twenty-first Amendment.

3. The States' "Core Powers." As Midcal, Capital Cities, and Bacchus establish, a state alcoholic beverage regulation that discriminates against interstate commerce can be saved from invalidation under dormant Commerce Clause analysis only if it was enacted under a "core power" conferred by the Twenty-first Amendment. ${ }^{105}$ Recently, in North Dakota $v$. United States, the Supreme Court reiterated that the core concerns of the Twenty-first Amendment are state laws that promote temperance and laws that regulate the sale, use, and distribution of alcoholic beverages. ${ }^{106}$ The Supreme Court's focus on core powers has restricted the scope of Twenty-first Amendment even further than recent opinions explicitly indicate. If a state cannot point to a core power as the justification for a restriction of trade in alcoholic beverages, the law stands little chance of surviving a Commerce Clause challenge.

The Supreme Court's narrowing of state authority to regulate commerce in alcoholic beverages in its recent jurisprudence, along with the development of the Commerce Clause/Twenty-first Amendment balancing test, provides valuable guidance for navigating this interpretive quagmire. There is lingering uncertainty, however, as to how much leeway the Court will afford states to decide how best to

\footnotetext{
104. Id.

105. In Midcal, the Court characterized the scope of Twenty-first Amendment protections as applying to laws regulating importation, sale, and distribution of alcoholic beverages. See California Retail Liquor Dealers Assoc. v. Midcal Aluminum, Inc., 445 U.S. 97, 110 (1980). In Capital Cities the Supreme Court referred to state regulation of the sale or use of liquor within its borders as "the core $\S 2$ power." Capital Cities Cable, Inc. v. Crisp, 467 U.S. 691, 713 (1984). Recall that in Bacchus the state could only seek the protections of the Twenty-first Amendment for its liquor tax if it could show that the tax "was designed to promote temperance ... [or a] clear concern of the Twenty-first Amendment." Bacchus, 468 U.S. at 276.

106. 495 U.S. 423 (1990); see also Pete's Brewing Co. v. Whitehead, 19 F. Supp. 2d 1004, 1018-19 (W.D. Mo. 1998) (identifying the promotion of temperance, regulation of sale or use of liquor, and regulation of alcoholic beverage distribution systems as states' core powers under the Twenty-first Amendment).
} 
exercise their core powers. The remaining confusion is fueled, at least in part, by the chasm that is developing between the authority the Supreme Court says the Twenty-first Amendment grants to states and the Supreme Court's application of the Amendment in cases raising Commerce Clause challenges to state liquor regulations.

Although the Court continues to mouth the words first uttered in Midcal - that states have "virtually complete control over whether to permit importation or sale of liquor and how to structure the liquor distribution system" "107_-in practice the Court gives little deference to a state's assertion that a challenged liquor regulation was enacted pursuant to a core power of the Twenty-first Amendment. For example, in 324 Liquor Corp. v. Duffy, an antitrust case, the Supreme Court scoffed at the state's argument that a price control statute was aimed at promoting temperance (even though the law itself explicitly stated temperance as one of its objectives) and found that the Twenty-first Amendment did not immunize the statute from the Sherman Act. ${ }^{108}$

In deed, if not in word, the Court all but abandoned its earlier notion that state laws enacted even under core powers of the Twentyfirst Amendment were free from the constraints of the dormant Commerce Clause in Healy v. Beer Institute. ${ }^{109}$ In Healy, the Supreme Court invalidated a Connecticut law that required out-of-state alcoholic beverage dealers to affirm that they were not charging higher prices to Connecticut wholesalers than they were charging to wholesalers in surrounding states, finding that the law contravened the dormant Commerce Clause because it affected liquor prices in other states. ${ }^{110}$ Justice Scalia concurred separately in Healy because he found the Court's analysis unnecessarily expansive. ${ }^{111}$ Justice Scalia argued that " $[\mathrm{t}]$ he Connecticut statute's invalidity is fully established by its facial discrimination against interstate commerce. This is so despite the fact that the law regulates the sale of alcoholic beverages, since its discriminatory character eliminates the immunity afforded by the Twenty-first Amendment."

107. 324 Liquor Corp. v. Duffy, 479 U.S. 335, 346 (1987) (quoting Midcal, 445 U.S. at 110).

108. 479 U.S. 335 (1987).

109. 491 U.S. 324 (1989).

110. See id. at 341 .

111. See id. at 344 (Scalia, J., concurring).

112. Id. (Scalia, J., concurring). 
These recent Supreme Court decisions reveal that no state liquor laws are immune from potential invalidation under the dormant Commerce Clause, even if enacted under core powers.

\section{Application of the Commerce Clause/Twenty-first Amendment Balancing Test}

Since the Supreme Court announced its important decision in Bacchus, several lower federal courts have applied and extended the Commerce Clause/Twenty-first Amendment balancing test with consistent results: ${ }^{113}$ in almost every case in which a state liquor regulation has been found to discriminate against interstate commerce, the courts have held that the law is not saved by the Twenty-first Amendment.

In Loretto Winery Ltd. v. Gazzara, the United States District Court for the Southern District of New York invalidated a New York state law that forbade retail grocery stores from selling wine coolers except those containing wine made exclusively from grapes grown in New York. ${ }^{114}$ Not surprisingly, the Loretto Winery court found that this law discriminated against interstate commerce. ${ }^{115}$ More striking, however, was the court's weighing of the state's Twenty-first Amendment defense that the law effectively limited sales of these alcoholic beverages and thereby promoted temperance. Balancing the state's interest in exerting core Twenty-first Amendment powers with the concern of the dormant Commerce Clause in promoting free interstate commerce, ${ }^{116}$ the court held that "[w]hatever the state interest in limiting the sale of a 'wine product,' it is clear that such interest could be served equally well by resorting to alternatives less burdensome to interstate commerce." ${ }^{, 17}$ Thus, even though the court acknowledged that the state was acting pursuant to a core power of the

113. Suits challenging state laws that restrict direct shipping are currently pending in several jurisdictions, which will afford ample opportunity for application of the Commerce Clause/Twenty-first Amendment balancing test. See Julie Hyman, Wineries Press for Lifting of Interstate Shipping Ban, WASH. TIMES, Feb. 4, 2000, at B8 (noting that five suits challenging states' anti-direct-shipping laws had been filed in the previous 18 months).

114. 601 F. Supp. 850, 859 (S.D.N.Y. 1985), aff'd sub. nom. Loretto Winery, Ltd. v. Duffy, 761 F.2d 140 (2d Cir. 1985).

115. See id. at 857-58 (declaring that "[u]nder traditional commerce clause jurisprudence, it is beyond dispute that the ABC Law would be unconstitutional, as discriminatory in both its purpose and its effect").

116. See id. at 861 ("[W]hat is to be balanced is the state interest in promoting 'temperance' with the federal constitutional interest in free trade across state lines.").

117. Id. at 863 . 
Twenty-first Amendment, it invalidated the law for interfering too greatly with the dormant Commerce Clause.

In Cooper v. McBeath ${ }^{118}$ the Fifth Circuit overturned a Texas law that provided that only state residents were eligible to obtain liquor licenses, finding that the state could enforce its liquor-licensing requirements without "prohibiting equal competition of non-Texans in the retail liquor business." 119 The Fifth Circuit rejected the State's defense that its liquor-license residency requirement maintained an orderly distribution system, promoted temperance and morals, and protected health and safety-all core state powers under the Twenty-first Amendment. ${ }^{120}$ Declaring that " $[\mathrm{t}]$ he core concerns underlying the Twenty-first Amendment are not entitled to greater weight than the principle of nondiscrimination animating the Commerce Clause," the Cooper court struck down the statute because the state failed to demonstrate that no less discriminatory alternatives could adequately protect the state's interests. ${ }^{121}$

Following the Fifth Circuit's lead in Cooper, the United States District Court for the Southern District of Texas recently granted summary judgment to plaintiffs raising a Commerce Clause challenge to a Texas direct-shipment law that prohibited unlicensed citizens from importing alcoholic beverages for personal consumption and restricted citizens from personally transporting more than three gallons of wine into the state. ${ }^{122}$ That case, styled Dickerson v. Bailey, was brought by Houston wine consumers who sought to purchase wines unavailable in the Houston retail market by ordering them directly from the wineries or by personally purchasing the wines at the wineries and then shipping the wines themselves to their homes in Texas. ${ }^{123}$ In applying the Commerce Clause/Twenty-first Amendment balancing test in her Dickerson opinion, Judge Harmon noted that, while the Supreme Court's Midcal and Idlewild opinions had indicated that the Court would be deferential to state liquor regulations enacted under core powers of the Twenty-first Amendment, the Court had modified that prior policy of unquestioning deference to

118. 11 F.3d 547 (5th Cir. 1994)

119. Id. at 554.

120. See id. at 554-55.

121. See id.

122. See Dickerson v. Bailey, 87 F. Supp. 2d 691, 709-10 (S.D. Tex. 2000).

123. See id. at 694-95. 
states' exercise of core powers to one of close scrutiny in Bacchus. ${ }^{124}$ Based on a review of the evolving Supreme Court and lower federal court jurisprudence applying the Commerce Clause/Twenty-first Amendment balancing test, Judge Harmon concluded that the Texas anti-direct-shipment law facially discriminated against interstate commerce and could not be saved by the Twenty-first Amendment because the state did not prove that there were no "reasonable nondiscriminatory alternatives" in exercising its core powers of "collect[ing] of taxes," "prohibiting delivery of alcoholic beverages to dry areas," and "prohibiting delivery of alcoholic beverages to minors."

In Bridenbaugh v. O'Bannon, Indiana wine collectors challenged that state's 1998 law prohibiting direct shipment of alcoholic beverages from persons outside the state to Indiana residents. ${ }^{126}$ In evaluating the plaintiffs' claim that the law violated the dormant Commerce Clause by preventing them from purchasing wines from other states and having them shipped to their residences, the United States District Court for the Northern District of Indiana interpreted the scope of states' core powers under section two of the Twenty-first Amendment so narrowly as to find the Commerce Clause/Twentyfirst Amendment balancing test inapplicable. ${ }^{127}$ Under its all-or-

124. See id. at 707 ("In applying the two-tier balancing test to challenged liquor statutes to determine first whether they discriminate against out-of-state interests and, if so, whether they are 'saved' by the twenty-first amendment, the courts have increasingly emphasized federal interests and more carefully scrutinized the actual purpose behind the state's law.").

125. Id. at 710. Judge Harmon may have gone a bit too far in her characterization of the discriminatory effects the Texas statute had on interstate commerce. Besides burdening the ability of Texas citizens to purchase wines produced in other states and cutting off Texas as a market to wineries that did not have access or had difficulty gaining access to the state's three-tier distribution system, Judge Harmon suggested that the law improperly attempted to regulate commerce in other states. See id. at 695. At first blush this line of reasoning seems plausible. Mail-order and Internet sales transactions do take place in the state where the seller, not the buyer, is located, as provided under U.C.C. $\$ 2-401(2)$ (a). The Texas statute at issue, however, did not forbid these types of transactions from taking place. See TeX. Alco. BEv. CodE AnN. § 107.07 (West 1995). Instead, the statute prohibited delivery of alcoholic beverages, however purchased, to unlicensed persons within the state unless the purchaser physically accompanied the shipment. See id. Thus, while prohibiting delivery of any alcoholic beverages legally purchased through mail-order or over the Internet may have the practical effect of deterring such transactions, the statute did not explicitly exert the type of extraterritorial regulation of commerce that Judge Harmon suggested and that the Supreme Court found unconstitutional in Healy v. Beer Inst., 491 U.S. 324 (1989) and Brown-Foreman Distillers Corp. v. New York State Liquor Auth., 476 U.S. 573 (1986).

126. 78 F. Supp. 2d 828, 829 (N.D. Ind. 1999).

127. See id. at 831 (declaring that "it is the conclusion of this Court that the State of Indiana cannot look to the Twenty-First Amendment for the constitutional salvation of the state statutes in question"). 
nothing interpretation of section two-the view that section two merely gave states and localities the option to remain dry after the repeal of Prohibition ${ }^{128}$ - the court perceived the issue in Bridenbaugh as "a straight forward application of the Commerce Clause." 129 Applying standard Commerce Clause analysis, ${ }^{130}$ the district court concluded that the Indiana anti-direct-shipment law facially and unjustifiably discriminated against interstate commerce and was therefore invalid. ${ }^{131}$

These recent cases applying the Supreme Court's Commerce Clause/Twenty-first Amendment balancing test have demonstrated that when a state regulation of alcoholic beverages interferes with interstate commerce, even a regulation enacted under the core powers of section two, the regulation must survive dormant Commerce Clause scrutiny. Such state laws will be given little, if any, greater deference because of the Twenty-first Amendment than state laws impacting interstate commerce that have no independent constitutional protection. These recent decisions have grave implications for many states that currently prohibit direct shipments of alcoholic beverages to their citizens.

\section{State Alcoholic BeVERAge Direct-ShiPMENT REGULATIONS}

The first three parts of this Note have addressed generally the tensions that exist between the dormant Commerce Clause and the Twenty-first Amendment, and the evolving interpretation of state powers under the Amendment. Since the Supreme Court's reading of the Twenty-first Amendment has narrowed, and the number of small wineries has expanded dramatically since the $1960 \mathrm{~s},{ }^{132}$ the constitutionality of state laws that restrict or prohibit the direct shipment of alcoholic beverages from out-of-state producers or retailers to consumers is in doubt.

128. As the Bridenbaugh court noted, the plain meaning and the legislative history of section two of the Twenty-first Amendment do reasonably support reading the Amendment as providing states the limited power to choose to remain dry. See supra Part II. Nevertheless, the Bridenbaugh court is the only modern court that has reached that interpretive conclusion.

129. Bridenbaugh, 78 F. Supp. 2 d at 831.

130. For a review of standard dormant Commerce Clause analysis, see supra Part I.A.

131. See Bridenbaugh, 78 F. Supp. $2 \mathrm{~d}$ at 832 (holding that "these statutes on their face discriminate against out of state commerce. ... [T] his Court has no choice but to declare these Indiana statutes in conflict with the Commerce Clause of Article I of the Constitution").

132. See supra notes $12-15$ and accompanying text. 
Although states point to section two of the Twenty-first Amendment as granting them explicit authority to restrict or prohibit direct shipment of alcoholic beverages notwithstanding the dormant Commerce Clause, our review of the text, legislative history, and Supreme Court jurisprudence of the Amendment has shown that this notion of unrestricted state power to interfere with interstate commerce in intoxicating liquors is overstated ${ }^{133}$ In fact, the most recent interpretations of the Supreme Court's Commerce Clause/Twentyfirst Amendment balancing test suggest that many of these state laws, if challenged, would not pass constitutional muster. For purposes of this analysis, states regulating direct shipments of alcoholic beverages can be classified into the following three categories: (1) states that permit direct shipments in limited quantities, ${ }^{134}(2)$ states that permit reciprocal direct shipments, ${ }^{135}$ and (3) states that prohibit all direct

133. See supra Parts I-III.

134. Alaska, Connecticut, Delaware, District of Columbia, Louisiana, Nebraska, Nevada, New Hampshire, North Dakota, and Rhode Island permit limited direct shipment, although some of these states impose limitations or requirements on the producer and/or the consumer. See Opinion of Alaska Att'y Gen., June 25, 1953 (stating that unlicensed individuals may import a reasonable quantity of alcoholic beverages for personal use); CONN. GEN. STAT. ANN. § 12436 (West 1999) (providing that individuals may import limited quantities of alcoholic beverages purchased by the individual within the United States for personal consumption); DEL. CODE ANN. tit. 4, § 526 (1999) (permitting, as of June 1, 2000, Delaware adult citizens to purchase for personal consumption limited quantities of beer and wine not readily available in the state from producers and retailers in other states); D.C. CODE ANN. § 25-137 (1999) (allowing very limited quantities of alcoholic beverages to be shipped directly to residents); LA. REV. STAT. ANN. $\S$ 26:359 (West 1999) (allowing direct shipment of no more than four cases of wine per year from a licensed manufacturer or retailer in another state to an adult Louisiana resident, provided the shipper obtains a direct shipping permit from Louisiana and pays all state liquor taxes); NEB. REV. STAT. § 53-194.03 (1999) (permitting direct shipment of up to nine liters of alcoholic liquor per month to a Nebraska resident for the resident's personal use); NEV. REV. STAT. $§ 369.490$ (1999) (prescribing that a Nevada resident may import directly from another state up to twelve cases of wine per year for personal use); N.H. REV. STAT. ANN. § 178:14-a (1999) (allowing an out-of-state manufacturer, importer, wholesaler, or retailer licensed in its domiciliary state to direct-ship no more than sixty one-liter containers of alcoholic beverages per year to any New Hampshire consumer, provided the shipper obtains a direct shipper's permit and pays a tax on all shipments); N.D. CENT. CODE § 5-01-16 (1999) (legalizing direct shipment of up to nine liters per month from an out-of-state location to an adult North Dakota resident); R.I. GEN. LAws $\S \S$ 3-1-1, 3-4-1 (1999) (defining "import" as transport into the state of more than three gallons of wine in a single shipment and thus not proscribing the direct shipment of wine in quantities less than three gallons per shipment).

135. California, Colorado, Idaho, Illinois, Iowa, Minnesota, Missouri, New Mexico, Oregon, Washington, West Virginia, and Wisconsin permit direct shipments from retailers or producers in other states but only from states that have reciprocal provisions. See CaL. Bus. \& Prof. CODE $§ 23661.2$ (West 1999) (providing that unlicensed adult residents may "receive a shipment of wine ... from any state of the United States that allows adult residents of that state to receive ... shipments . . . from California”); COLO. REv. STAT. § 12-47-104 (1999) ("[T]he holder 


\section{shipments. $^{136}$}

of an alcoholic beverage license that authorizes the manufacture of vinous liquors in a state that affords Colorado adults or licensees an equal reciprocal shipping privilege may ship ... vinous liquors ... to any adult resident of this state.”); IDAHO CODE $§ 23-1309$ A (1999) (permitting residents over twenty-one years of age to receive by direct shipment no more than two cases of wine per month for personal consumption from another state, but only if the state from which the wine is shipped allows its residents to receive direct shipments of wine from Idaho); 235 ILL. COMP. STAT. 5/6-29 (West 1999) (providing that adult residents and holders of alcoholic beverage licenses of other states may direct-ship up to two cases of wine per year to any adult Illinois resident, provided that the shipper resides in a state that affords a reciprocal shipping privilege to Illinois adult residents or alcoholic beverage licensees); IOWA CODE § 123.187 (1999) (allowing wineries in other states to direct-ship by common carrier no more than eighteen liters of wine per month for personal consumption to adult Iowa residents, but only if the state where the shipping winery is located affords a reciprocal shipping privilege to Iowa wineries); MINN. STAT. ANN. § 340A.417 (West 1999) ("[A] winery licensed in a state which affords Minnesota wineries an equal reciprocal shipping privilege ... may ship, for personal use and not for resale, not more than two cases of wine ... in any calendar year to any resident of Minnesota age 21 or over.”); MO. ANN. STAT. $\$ 311.462$ (West 1999) (providing that adult residents or licensed liquor sellers in a state that permits Missouri residents or licensees a reciprocal shipping privilege may ship no more than two cases of wine to an adult Missouri resident for personal use); N.M. STAT. ANN. § 60-7A-3 (Michie 1999) (permitting direct shipment of up to two cases of wine per month from out-of-state persons to adult New Mexico residents, provided the shipper's state affords New Mexico residents equal reciprocal shipping privileges); OR. REV. STAT. § 471.229 (1999) (sanctioning the tax-free direct shipment of two cases per month of wine from another state to an adult Oregon resident, provided the wine is sent from a state that permits its residents to receive wine shipments from Oregon tax-free); WASH. REV. CODE § 66.12.190 (1999) (permitting out-of-state wine manufacturers to ship no more than two cases of wine per year to a Washington resident for the resident's personal use, provided the manufacturer first obtains an out-of-state wine shipping license); W. VA. CODE § 60-8-6 (1999) (allowing out-of-state sellers of alcoholic beverages licensed in their state of domicile to ship up to two cases of wine per month to any adult West Virginia resident, provided the shipper's state permits West Virginia residents a reciprocal shipping privilege); WIS. STAT. §§ 125.58, 125.68(10) (1999) (authorizing direct shipment from on out-of-state winery to a state resident of up to nine liters of wine per year without an out-of-state shipper's permit, provided the state in which the winery is located has entered a reciprocity agreement with Wisconsin).

136. Alabama, Arizona, Arkansas, Florida, Georgia, Hawaii, Indiana, Kansas, Kentucky, Maine, Maryland, Massachusetts, Michigan, Mississippi, Montana, New Jersey, New York, North Carolina, Ohio, Oklahoma, Pennsylvania, South Carolina, South Dakota, Tennessee, Texas, Utah, Vermont, Virginia, and Wyoming have enacted laws which either explicitly criminalize direct shipment from producers to customers or do so implicitly by requiring that all commerce in alcoholic beverages be transacted through state-enforced distribution systems. See Ala. Alco. Bev. Contr. Bd. Rules \& Regulations 20-X-8.04(1) (last updated Mar. 15, 2000) <www.abcboard.state.al.us/rrch8.html> (on file with the Duke Law Journal) ("No alcoholic beverages may be delivered from outside Alabama to any person ... within the state, except to the ABC Board and to manufacturers, importers, wholesalers and warehouses licensed by the ABC Board."); ARIZ. REV. STAT. ANN. § 4-250.01 (West 1999) (prohibiting out-of-state retailers and producers from violating any statutory provisions governing alcoholic beverage distribution, which thereby prohibits these parties from shipping directly to unlicensed in-state customers); ARK. CODE ANN. § 3-7-106 (Michie 1996) (making it "unlawful for any person to ship or transport... into the State of Arkansas any spirituous liquors, vinous liquors, wines other than Arkansas wines, or beer or malt beverages from points without the state" for those 
lacking a state license); FLA. STAT. ANN. $\$ 561.545$ (West 2000) (criminalizing direct shipment from out-of-state locations to any unlicensed person in the state and making certain repeat violations of the section a felony); GA. CODE. ANN. § 3-3-32 (1999) (prohibiting all direct shipment of alcoholic beverages from out-of-state sellers to unlicensed Georgia residents and making successive violations a felony); HAW. REV. STAT. ANN. §§ 281-3, 281-33.1 (Michie 2000) (making direct shipments from out-of-state locations to persons in the state illegal, subject to a once-peryear exception for no more than five gallons shipped to a resident who has first met the requirements of and obtained a special permit); IND. CODE $\S \S 7.1-5-1-9.5,7.1-5-11-1.5$ (Michie 1999) (proscribing direct shipment of alcoholic beverages from persons or businesses in other states to unlicensed Indiana residents and stating that a violation of this provision by a party not holding a basic permit is a felony); KAN. STAT. ANN. § 41-104 (1993) (prohibiting all acts regarding alcoholic beverages not specifically allowed by statute, including direct shipping of alcoholic beverages to Kansas consumers); KY. REV. STAT. ANN. § 244.165 (Banks-Baldwin 2000) (making direct shipment by a seller of alcoholic beverages in another state to an unlicensed Kentucky resident illegal, a violation of which, after the first warning, is a felony); ME. REV. STAT. ANN. tit. 28-A, § 2077-B (West 1999) ("A person may not sell, furnish, deliver or purchase liquor from an out-of-state company by mail order.”); MD. ANN. CODE art. 2B, § 16-506.1 (1999) (making the shipment of alcoholic beverages, including alcoholic beverages purchased over a computerized network, to an unlicensed recipient in the state of Maryland a felony); MASS. ANN. LAWS ch. 138, § 2 (Law. Co-op. 1995) (prohibiting transportation and importation of alcoholic beverages except as authorized by the chapter with no other authorization of direct shipment from out-of-state manufacturers or retailers to unlicensed Massachusetts residents); MiCH. COMP. LAws ANN. § 436.3 (West 1998) (notwithstanding an exception that "a person who is of legal age to purchase alcoholic liquor may import from another state for that person's personal use not more than 312 ounces of alcoholic liquor that contains less than $21 \%$ alcohol by volume," the Michigan statute prohibits "delivery" of alcoholic beverages, including for personal use, by any "person" other than the state liquor commission, which leads to the reasonable interpretation that the term "import" in the exception includes only in-person transportation); MISS. CODE ANN. § 97-31-47 (1994) (criminalizing unlicensed importation into or delivery in Mississippi of alcoholic beverages); MONT. CODE ANN. § 16-3-402 (1999) (providing that wines manufactured outside the state may only be shipped into the state if consigned and delivered to a Montana-licensed distributor and unloaded by the distributor into the distributor's warehouse); N.J. STAT. ANN. § 33:1-2 (West 1999) (allowing in-person importation of a limited quantity of alcoholic beverages but making no similar exception to the general ban on unlicensed importation for direct shipping); N.Y. ALCO. BEV. CONT. LAW $§ 102$ (McKinney 1987 \& Supp. 1999) (proscribing unconditionally the shipping into New York of alcoholic beverages from another state, unless the shipment is consigned and delivered to a duly licensed recipient); N.C. GEN. STAT. § 18B-102.1 (1999) (making it a felony for an out-of-state seller to direct-ship alcoholic beverages to any North Carolina resident who is not a licensed wholesaler); OHIO REV. CODE ANN. $\S \S 4301.19,4301.20$ (West 1999) (prohibiting direct shipment to or importation, with the exception of minimal quantities transported in-person, by a party who does not have a state permit); OKLA. STAT. ANN. tit. 37, § 505 (West 1999) ("[I]t is unlawful for any manufacturer, wholesaler or retailer of alcoholic beverages, located and doing business from outside this state, to make retail sales of alcoholic beverages to purchasers located in this state or to ship alcoholic beverages sold at retail to persons located in this state."); PA. STAT. ANN. tit. 47, § 4-491 (West 1997) (expressly prohibiting any person not licensed to import liquor from doing so by any means whatsoever); S.C. CODE ANN. § 61-2-175 (Law. Co-op. 1999) (forbidding the direct shipment of alcoholic beverages by a person or entity in another state to any unlicensed South Carolina resident); S.D. CoDIFIED LAws §§ 35-4-66, 35-4-67 (Michie 1999) (permitting shipments of alcoholic beverages, other than beer, into the state from a point outside of the state to be delivered only to persons licensed to receive such shipments); TENN. CODE ANN. $\S \S 57-3-401,57-3-402$ (1999) (proscribing as a first-offense felony importation or direct shipment 
State laws that permit direct shipment of alcoholic beverages from producers or retailers to consumers in limited quantities will likely survive scrutiny under the dormant Commerce Clause, at least insofar as those laws do not apply disproportionately to out-of-state producers or retailers. State laws that favor in-state producers or retailers over out-of-state producers or retailers will be indefensible. ${ }^{137}$ It is difficult to conjure up a justification for permitting in-state producers and retailers to have broader direct-sales or direct-shipping authority than is allowed to out-of-state producers or retailers, other than economic protectionism. It is no less likely that an in-state winery will sell or ship to a minor, that alcoholic beverages purchased from an in-state winery will be diverted into illegal channels of distribution, or that state citizens will get drunk on in-state wine than if the wine shipment crosses a state line.

States that have enacted reciprocal direct-shipping laws, while preferable from the consumer's perspective relative to outright prohibition, are also particularly flagrant in their violation of the dormant Commerce Clause. Again, it is difficult to conceive of a core Twenty-first Amendment concern furthered by a state reciprocity requirement. Exactly how alcoholic beverages being shipped from reciprocity states are less likely to end up in the hands of minors or in a state's black market, or to result in drunkenness, than wine purchased and shipped from non-reciprocity states is hard to fathom.

of alcoholic beverages for delivery to any person not holding a wholesaler's permit); TEX. AlCo. BEv. CODE ANN. $\$ 107.07$ (West 2000) (outlawing, subject to exceptions for small amounts, importation of alcoholic beverages for the personal use of a Texas resident not holding an importer's permit unless the resident personally accompanies the beverages across the state line); UTAH CODE ANN. §§ 32A-1-109, 32A-8-501, 32A-12-503 (1999) (prohibiting the importation of alcoholic beverages by any party other than the state or state licensees); VT. STAT. ANN. tit. 7, $\$ 63$ (1999) (banning importation or transportation of wine into the state by persons not holding an importer's permit); VA. CODE ANN. § 4.1-310 (Michie 1999) (criminalizing importation and shipment of wine into the state unless consigned to a licensed wholesaler); WYO. STAT. ANN. §§ 12-2-203, 12-3-101 (Michie 1999) (forbidding importation or transportation of alcoholic beverages into the state for use or consumption therein without having paid excise taxes and holding importer's permit).

137. Arkansas, South Carolina, South Dakota, and Tennessee are examples of states that expressly discriminate against out-of-state producers or retailers in their direct-shipment laws. See ARK. CODE ANN. §§ 3-1-103, 3-7-106 (Michie 1996) (exempting manufacturers, distributors, and retailers of Arkansas wines from that state's law prohibiting direct shipments); S.C. CODE ANN. § 61-4-720 (Law. Co-op. 1999) (permitting in-state wineries to sell, deliver, and ship wines directly to consumers' homes whether inside or outside of the state); S.D. CODIFIED LAWs $\S 35-$ 12-5 (Michie 1999) (allowing domestic farm wineries to sell wine directly to consumers); TENN. CODE ANN. § 57-3-207 (1999) (providing that wineries using primarily Tennessee agricultural products may sell wines directly to consumers). 
State laws that absolutely prohibit direct shipment from both instate and out-of-state producers to consumers require close scrutiny in balancing the states' exercise of core Twenty-first Amendment powers with the primary purpose of the dormant Commerce Clause. States insist that prohibition of direct shipments is necessary to prevent minors from accessing alcoholic beverages, to maintain an orderly alcoholic beverage distribution system, and to promote temperance. ${ }^{138}$ Each of these concerns, however, can be addressed in a less restrictive manner than absolute prohibition of direct shipments. For example, the concern that children are purchasing or will gain access to alcoholic beverages by ordering them directly from the producers, even if valid, could be resolved by much less discriminatory means than prohibiting direct shipment altogether, such as age verification requirements. ${ }^{139}$ Similarly, states cannot legitimately claim that directshipment bans are necessary to protect state tax revenues; a very small percentage of state revenues are derived from taxation of alcoholic beverages, and an even smaller percentage would be lost if direct shipments were permitted. ${ }^{140}$ If direct shipments were allowed, the states that have a sales tax would still lose much more revenue on untaxed interstate mail-order and e-commerce transactions not involving alcoholic beverages than they would on untaxed liquor transactions. Furthermore, states are actively working on a solution to effectively tax mail-order and e-commerce transactions, and whatever solution they find will be equally useful in taxing direct shipments of alcoholic beverages. The most promising defense states can make of direct-shipment bans is that complete prohibition of these transactions is necessary to promote temperance and to maintain an orderly system of alcoholic beverage distribution. This argument is much

138. See Clint Bolick, Wine Wars: Lift the Ban on Out-of-State Sales, WALL ST. J., Feb. 7, 2000, at A29 (noting that "[s]tate officials cite temperance and taxes," as well as the protection of minors, as their reasons for enacting laws that prohibit direct shipment of alcoholic beverages); Wine \& Spirits Wholesalers of America, Direct Shipments Threaten State Alcohol Tax and Control Laws (visited Aug. 22, 2000) <http://www.wswa.org/dir_ship/threaten.htm> (on file with the Duke Law Journal) (warning that "direct sales to consumers by out-of-state businesses, in most cases, avoid state excise and sales taxes ... [and] also bypass laws against selling to underage persons"); supra note 125 and accompanying text.

139. See infra notes 156-157 and accompanying text.

140. See Bolick, supra note 138, at A39 (noting that since winery trade associations are willing to pay state liquor taxes on direct shipments, states are actually forgoing tax revenues by prohibiting direct shipments); John Malmo, Wine Bill Protects Business, Not Kids, THE CoM. APPEAL, Sept. 20, 1999, at B4 (commenting that states' interest in prohibiting direct shipments "is not about state tax revenue, because wine taxes are peanuts compared with other interstate shipments direct to consumers"). 
more tenable than the underage drinking and taxation arguments because it is at least a colorable exercise of the core powers granted to states by the Twenty-first Amendment. Faced with this defense, the question becomes whether laws that prohibit direct shipments of alcoholic beverages are sufficiently tied to the states' core powers under the Twenty-first Amendment-and are the least discriminatory means available to enforce those core powers-to outweigh ordinary dormant Commerce Clause concerns. ${ }^{141}$

The Supreme Court's Twenty-first Amendment jurisprudence suggests, and lower federal courts have said explicitly, that states cannot completely prohibit direct shipments of alcoholic beverages under the cloak of Twenty-first Amendment core powers. Furthermore, there are less discriminatory ways to accomplish the states' core power goals. ${ }^{142}$ For example, most states have laws, independent of direct-shipment regulations, that criminalize sales of alcoholic beverages to minors and make distribution of liquor by unlicensed persons unlawful. As Parts V and VI demonstrate, states can accomplish their core power goals without recourse to blanket prohibition of all direct shipments.

\section{RECENT CONGRESSIONAL INVOLVEMENT IN THE DIRECT- SHIPPING FRAY}

Congress has not remained on the sidelines during this period of increasing tension between proponents of direct sales of alcoholic beverages, including those made on the Internet, and states' antidirect-shipment laws-a conflict that is currently being played out in federal courts. In 1999, supporters of state direct-shipping prohibitions proposed the Twenty-first Amendment Enforcement Act, which would permit states to enforce their direct-shipment laws against outof-state violators in federal court. ${ }^{143}$ Although such a federal procedural intervention, as opposed to substantive legislation by Congress expressly yielding power over interstate commerce in alcoholic bev-

141. See Bacchus Imports, Ltd. v. Dias, 468 U.S. 263, 275 (1984) ("The question in this case is ... whether the principles underlying the Twenty-first Amendment are sufficiently implicated by the [state law] to outweigh the Commerce Clause principles that would otherwise be offended."); see also supra Part III.C (describing how lower federal courts have balanced Twentyfirst Amendment and Commerce Clause concerns).

142. See supra Part III.C.

143. Both the House and Senate versions of the proposed Twenty-first Amendment Enforcement Act were drafted as amendments to the Webb-Kenyon Act, ch. 90, 37 Stat. 699 (1913) (codified at 27 U.S.C. § 122) (1994). 
erages to the states ${ }^{144}$ would do nothing to clarify the muddy confluence of state power under the Twenty-first Amendment and the restrictions of the dormant Commerce Clause, the debate in Congress surrounding the Twenty-first Amendment Enforcement Act provides additional insight into the current status of the interstate liquor marketplace and state direct-shipment laws.

On March 10, 1999, Senator Orrin Hatch introduced Senate Bill 577-a version of the Twenty-first Amendment Enforcement Act that would permit a state attorney general to seek an injunction in federal court to prevent the importation or transportation of alcoholic beverages in violation of that state's law. ${ }^{145}$ In proposing the Bill, Senator Hatch relayed a story about a Salt Lake City thirteen-year-old who used a borrowed credit card to purchase beer over the Internet and

144. In 1913, before the constitutionalization of the national debate over alcoholic beverages by the Eighteenth and Twenty-first Amendments, Congress passed legislation entitled "An Act Divesting intoxicating liquors of their interstate character in certain cases," better known as the Webb-Kenyon Act, which provided, in relevant part:

[T]he shipment or transportation, in any manner or by any means whatsoever, of any ... intoxicating liquor of any kind, from one State, Territory, or District of the United States ... into any other State, Territory, or District of the United States ... which said ... intoxicating liquor is intended, by any person interested therein, to be received, possessed, sold, or in any manner used... in violation of any law of such State, Territory, or District of the United States . . is hereby prohibited.

Id. at 699-700. Much like the text of the Twenty-first Amendment, the Webb-Kenyon Act was susceptible to conflicting interpretations. States argued that the Act gave them plenary authority to regulate all imported alcoholic beverages, but others contended that the Act merely empowered statutory dry states to enforce their prohibition laws. See Sidney J. Spaeth, Note, The Twenty-first Amendment and State Control Over Intoxicating Liquor: Accommodating the Federal Interest, 79 CAL. L. REV. 161, 174 n.87 (1991) (noting that both the Supreme Court and the Texas Court of Criminal Appeals endorsed a limiting construction of the Webb-Kenyon Act). Some opponents of the Act, including President Taft, even challenged its constitutionality. See $i d$. at 173-75. Although a divided Supreme Court upheld the Act in Clark Distilling Co. v. Western Md. Ry. Co., 242 U.S. 311, 331-32 (1917), it did not overturn its earlier interpretation in $A d$ ams Express Co. v. Kentucky, 238 U.S. 190, 199 (1915), that the Act only operated to protect dry states. Ratification of the Eighteenth Amendment, of course, rendered debate over the WebbKenyon Act moot. Webb-Kenyon was reenacted without modification by Congress in 1935, however, following repeal of national Prohibition by the Twenty-first Amendment. WebbKenyon Act, ch. 740, § 202(b), 49 Stat. 877 (1935) (codified at 27 U.S.C. § 122 (1994)). Although one might point to Webb-Kenyon and argue that it constitutes a delegation of authority to regulate interstate commerce in alcoholic beverages to the states, the Twenty-first Amendment notwithstanding, the proper interpretation of that Act is no less controversial than the interpretation of section two of the Twenty-first Amendment. Full treatment of the former controversy is not addressed in this Note, which is devoted to consideration of the latter. Nevertheless, disregard of the Webb-Kenyon Act in recent Supreme Court and lower federal court opinions relevant to the direct shipping debate suggests that the Act will not save state regulations that run afoul of the dormant Commerce Clause if the Twenty-first Amendment is not their savior.

145. See 145 Cong. REC. S2503 (daily ed. Mar. 10, 1999) (statement of Sen. Hatch) (introducing S. 577, 106th Cong. (1999)). 
received mail-order delivery with no questions asked. ${ }^{146}$ Senator Hatch presented this tale to demonstrate that "modern technology has opened the door for abuse and created the need for further governmental action to address [illegal selling of alcohol to minors]. No longer must a State prosecute just an errant neighborhood retailer for selling to a minor-now, the ones selling to minors ... are a continent away." ${ }^{147}$ Senator Robert Byrd, supporting a modified version, made a similar argument by citing statistics that during the month of April 1999, "approximately 34 percent of high school seniors, 22 percent of tenth graders, and 8 percent of eighth graders... [got] drunk" as strong evidence of why the Twenty-first Amendment Enforcement Act was necessary. ${ }^{148}$ Senator Byrd warned that "children can now get beer, wine, or liquor sent directly to their homes by ordering from catalogues or over the Internet," and admonished that "direct-toconsumer sales work to undermine the extremely important controls currently in place in many of our States." 149

Representative Joe Scarborough presented H.R. 2031, the House version of the Twenty-first Amendment Enforcement Act, on June 7, 1999. ${ }^{150}$ Representative Scarborough accused those who would sell alcoholic beverages over the Internet of being "modern-day bootleggers," and argued that distribution via states' three-tiered systems is necessary to prevent minors from purchasing alcoholic beverages. ${ }^{151}$ Representative Moakley of Massachusetts explained the purpose of the Twenty-first Amendment Enforcement Act to the members of the House like this: "It says you cannot ship alcohol into a State in violation of that State's liquor laws. It is that simple."152 Representa-

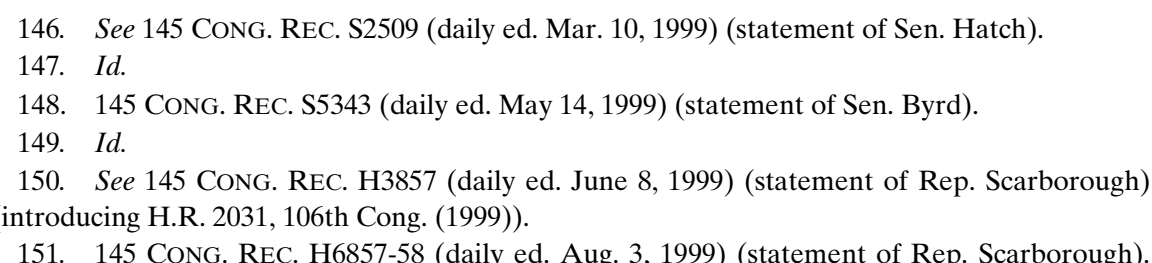
Members of the wine industry suggest that supporters of the Twenty-first Amendment Enforcement Act and similar legislation in Congress may not be primarily motivated by their interest in preventing minors from ordering wine over the Internet. See Eckstein, supra note 3, at 1. Instead, they propose that supporters may be more influenced by the powerful lobbies supported by alcohol wholesalers and distributors, the most powerful member of which is Southern Wine \& Spirits of America Inc., located in Rep. Scarborough's home state. See id. Wholesalers and distributors have reason to fear direct sales of wine and other alcoholic beverages over the Internet because if direct sales are permitted, their services as "middlemen" in wine sales will no longer be necessary. See id.

152. 145 CONG. REC. H6857 (daily ed. Aug. 3, 1999) (statement of Rep. Moakley). 
tive Moakley went on to say that "[the Twenty-first Amendment Enforcement Act] is not a new Federal law, it is not a new State law ... [i]t is just a way for State attorneys general to get people who sell alcohol illegally to stop." 153

Opponents of the Twenty-first Amendment Enforcement Act contend that both of the asserted justifications for the Act-the need to protect minors and the need to protect state tax revenues-are merely subterfuge, covering the real purpose-protecting wholesalers and retailers from competition from producers and out-of-state retailers who want to sell their products directly to consumers. ${ }^{154}$ They argue persuasively that state attorneys general and federal legislators are already working to determine how states can collect taxes on burgeoning interstate mail-order and Internet sales. ${ }^{155}$ Opponents of the Act maintain, moreover, that federal legislation to enforce state direct-shipment restrictions will do little to prevent underage drinking because "a minor ordering wine out-of-state by Internet or mail with a credit card, then waiting for shipment... [is a] lot less likely than snitching some from Mom and Dad's supply, or with a bogus ID, or from a surrogate buyer." "156 Representative Woosley characterized the proposed legislation as "a wolf in sheep's clothing," accusing its supporters of hiding behind claims of states' rights and preventing teenagers from buying alcoholic beverages over the Internet, when their real motive is appeasing liquor wholesalers and distributors that do not want their three-tiered monopolies disrupted by direct sales. ${ }^{157}$

153. Id.

154. See, e.g., Malmo, supra note 140, at B4 ("As in so many knee-jerk reactions by Congress, this is just another lousy bill that restricts interstate commerce."). It is interesting to note that the most prominent supporters of the Twenty-first Amendment Enforcement Act outside of Congress are the organizations that represent state-sanctioned alcohol distribution monopolies and oligopolies: the Wine and Spirits Wholesalers of America, the National Beer Wholesalers Association, the National Licensed Beverage Association, and the National Alcohol Beverage Control Association. See 145 Cong. REC. S5344 (daily ed. May 14, 1999) (statement of Sen. Byrd) (citing these organizations, in addition to the American Academy of Pediatrics and the International Association of Chiefs of Police, as the organizations favoring the Twenty-first Amendment Enforcement Act).

155. See Malmo, supra note 140, at B4.

156. Id.; see also Lisa Greim Everitt, Wine Online: Direct Shipments on Web Spur 'Bootlegging' Debate, DenV. Rocky MTN. News, Sept. 27, 1999, at 1B ("Buying that $\$ 45$ Amarone to chug behind the high school with your friends takes a credit card, a three-to-seven-day wait and 'lying multiple times. To go to the local store, you only gotta lie once.'”) (quoting Bill Newlands of Virtual Vineyards, a California-based online wine retailer).

157. See 145 Cong. ReC. H6863 (daily ed. Aug. 3, 1999) (statement of Rep. Woolsey). Representative Woolsey characterized the three-tiered system of alcohol distribution that predominates state regulations as the result of three things: "Politics, policy, and profits." Id. 
Realizing that the Twenty-first Amendment Enforcement Act had broad support in the House, however, one opponent, Representative Goodlatte, offered a telling amendment to the Act moments before a vote was taken. ${ }^{158}$ The Goodlatte Amendment clarified that the Twenty-first Amendment Enforcement Act would not permit states to seek federal court injunctions to enforce state laws that discriminate against out-of-state sellers in favor of local interests-laws that amount to economic protectionism. ${ }^{159}$ The Amendment provided that "[n]o State may enforce under this Act a law regulating the importation or transportation of any intoxicating liquor that unconstitutionally discriminates against interstate commerce by out-of-State sellers by favoring local industries, thus erecting barriers to competition and constituting mere economic protectionism." 160 Representative Conyers noted that several Internet companies, including America Online, Bell Atlantic, Bell South, the Commercial Internet Exchange, Prodigy, and PSInet, had expressed strong support for the addition of the Goodlatte Amendment to the Twenty-first Amendment Enforcement Act to make explicit that the Act would in no way permit states to enforce protectionist state legislation in federal court. ${ }^{161}$ The House voted overwhelmingly to include the Goodlatte Amendment in their version of the Twenty-first Amendment Enforcement Act, as both members who supported and who opposed the Act argued that it was not "in anyway [sic] designed to supercede

158. See 145 Cong. REC. H6868 (daily ed. Aug. 3, 1999) (statement of Rep. Goodlatte).

159. See 145 Cong. ReC. H6869 (daily ed. Aug. 3, 1999) (statement of Rep. Cox) (cosponsoring the Goodlatte Amendment and clarifying that "States are free to regulate within their boundaries the sale, distribution and production of alcoholic beverages produced and sold elsewhere in order to promote temperance, in order to maintain their status as dry States or even counties to be dry counties, to promote those social purposes behind the 21st amendment[, but] a State cannot discriminate as mere economic protectionism against other sellers, other producers in the rest of the United States").

160. 145 CONG. REC. H6868 (daily ed. Aug. 3, 1999) (statement of Rep. Goodlatte).

161. See 145 Cong. ReC. H6871 (daily ed. Aug. 3, 1999) (statement of Rep. Conyers). Other Silicon Valley firms have also expressed concern that the Act might set a precedent of allowing states to enforce discriminatory, protectionist legislation just as the growth of the Internet promises to reshape interstate commerce. Intel, a very influential technology company, wrote a letter to Senate Judiciary Committee Chairman Orrin Hatch expressing its desire to have language similar to the Goodlatte Amendment included in the Senate version. See Carolyn Lochhead, Threat to Internet Sales Uncorks New Alliance; Napa and Silicon Valleys Join To Fight Wine Ban, S.F. CHRON., Oct. 18, 1999, at A1 (quoting Intel Vice President for Law and Government Affairs F. Thomas Dunlap, Jr., who asserted in his letter to Senator Hatch that "Intel, like other companies that are collectively building the new economy through the products and services which form the infrastructure of e-commerce, has a great stake in the preservation of an Internet free of discriminatory taxation and regulation"). 
any other provision of the Constitution, such as the first amendment or the Commerce clause (including the so-called 'dormant' Commerce clause)." ${ }^{162}$ The House passed H.R. 2031, as amended, on August 3, 1999. ${ }^{163}$

The Senate version of the Twenty-first Amendment Enforcement Act was referred to the Senate Committee on the Judiciary on the day it was proposed, March 10, 1999, and remained there until March 2, 2000, when an amended version was reported by Senator Hatch, Chairman of the Committee on the Judiciary. ${ }^{164}$ This amended version of the Act contained new language similar to the Goodlatte Amendment. ${ }^{165}$ If the Senate version passes, it would have to be reconciled with the House version before the Twenty-first Amendment Enforcement Act becomes law.

This discussion of the proposed Twenty-first Amendment Enforcement Act sheds further light on the interplay between the Twenty-first Amendment and the Commerce Clause for several reasons. First, the congressional debates present the states' principal arguments in defense of restrictions on direct shipments-the need to collect tax revenues on all sales of alcoholic beverages, concerns about underage drinking, and enforcement of states' three-tiered distribution systems. Second, the inclusion of language meant to ensure that the Act would not be construed to limit the effect of the Commerce Clause in prohibiting discriminatory state laws indicates Congress's understanding that the states' power to regulate direct shipments of alcoholic beverages is subject to, and not free from, the dormant Commerce Clause. Finally, this wave of federal action-action taken under the powers conferred on Congress, at least in part, by the Commerce Clause-suggests that the best balance between

\footnotetext{
162. 145 Cong. REC. H6871 (daily ed. Aug. 3, 1999) (statement of Rep. Conyers).

163. See 145 Cong. ReC. H6887 (daily ed. Aug. 3, 1999).

164. See 146 CONG. REC. S1117 (daily ed. Mar. 2, 2000) (statement of Sen. Hatch).

165. See S. 577, 106th Cong. (2000). The relevant amendment to S. 577 provides:

Rules of Construction. This section shall be construed only to extend the jurisdiction of Federal courts in connection with State law that is a valid exercise of power vested in the States-

(1) under the twenty-first article of amendment of the Constitution of the United States as such article of amendment is interpreted by the Supreme Court of the United States including interpretations in conjunction with other provisions of the Constitution of the United States; and

(2) under the first section herein as section such is interpreted by the Supreme Court of the United States; but shall not be construed to grant to States any additional power.
}

Id. $\S 2(\mathrm{e})$. 
states' rights to regulate the liquor trade under the Twenty-first Amendment and federal interests in protecting free interstate commerce may be reached through coordinated federal and state action.

\section{A Reasonable Resolution to the DiRECT-SHiPMENT DEBATE}

Neither the plain meaning of the text of the Twenty-first Amendment nor its legislative history resolves whether, and to what extent, the Amendment created a dormant Commerce Clause exception for state regulations of commerce in alcoholic beverages. Careful study of these sources reveals as much support for the narrow view that section two of the Amendment was intended to have the very limited effect of giving states the option to remain dry after repeal of Prohibition as it does for the broad view that section two completely exempted state regulation of commerce in intoxicating liquors from other constitutional provisions.

While Supreme Court decisions have focused the range of possibilities, even the Court's jurisprudence interpreting the effect of section two has evolved significantly. Immediately following ratification, the Court repeatedly held that the Twenty-first Amendment permitted states unfettered authority to regulate liquor traffic; more recently, the Court has abandoned the notion that the Amendment created a protective blanket for all state liquor laws in favor of a test that balances states' core powers under the Amendment with the dormant Commerce Clause. The recent wave of Commerce Clause challenges to state laws restricting direct shipments might soon present the $\mathrm{Su}$ preme Court with the opportunity to dispel the remaining uncertainty. Among the federal courts that have reached the merits in these recent challenges, a decidedly narrow interpretation of states' powers to regulate interstate commerce in alcoholic beverages has emerged. ${ }^{166}$ Whether these cases foretell of further narrowing of section two of the Twenty-first Amendment by the Supreme Court remains to be seen. What is evident from these challenges to state anti-directshipment laws is that section two cannot be read as exempting even state regulations of commerce in alcoholic beverages enacted under "core powers" of the Twenty-first Amendment from the provisions of the dormant Commerce Clause.

166. See supra Part III.C. 
Existing Twenty-first Amendment jurisprudence, guided by examination of the text, the history, and even recent congressional debate involving the Amendment, reveals sufficient room for a reasonable solution to the interpretive dilemma-a solution that balances state interests in regulating the peculiar threats that the liquor trade poses to their citizens with federal concerns for preventing statecreated barriers to interstate trade. A few enlightened states have moved their direct-shipment regulations toward this balance. These states have enacted laws that permit direct shipment of alcoholic beverages to consumers but incorporate more neutral safeguards that will likely survive Commerce Clause scrutiny. ${ }^{167}$

Despite the shift in jurisprudence, the constitutional right of states to regulate the manner of intrastate commercial liquor distribution is incontrovertible. Striking the necessary constitutional balance between the dormant Commerce Clause, which makes interstate commerce a uniquely federal concern, and the Twenty-first Amendment, which makes at least intrastate regulation of alcoholic beverages a uniquely state concern, requires a blending of legislative action by both Congress and the states. Federal legislation is necessary to regulate the interstate character of direct shipments, and state legislation is necessary to regulate the distribution of alcoholic beverages once carried into the state.

An existing federal statute makes it a crime knowingly to ship liquor in the United States in any package that is not clearly labeled with the name of the consignee and the nature and quantity of its contents. ${ }^{168}$ It is also a federal offense for any officer, agent, or employee of a common carrier knowingly to deliver a shipment of liquor to any person other than the person to whom the shipment has been consigned, unless upon written order of the consignee, or to any fictitious person, or to any person under a fictitious name. ${ }^{169}$ These federal criminal statutes shed a guiding light on the path that Congress and the states should follow in reaching a reasonable and constitutional resolution to the direct-shipment controversy. Congress, in collaboration with the states, should supplement these federal criminal laws with detailed regulations on wine and liquor producers that would be at least as effective as face-to-face buyer/seller encounters at preventing illegal sales of alcoholic beverages to minors. In a recent ses-

167. See supra Part IV.

168. See 18 U.S.C. $\$ 1263$ (1994).

169. See 18 U.S.C. $\$ 1264$ (1994). 
sion of Congress, Senator Feinstein proposed just such a set of amendments to the existing federal criminal statutes concerning interstate shipment and delivery of alcoholic beverages. ${ }^{170}$ Essentially, Senator Feinstein's proposal would require that any shipping package containing alcoholic beverages be clearly labeled as to the identification of its contents and that, upon delivery, an adult who has attained the age required by the state for lawful purchase and consumption of alcoholic beverages present identification and sign for the shipment. ${ }^{171}$ Such a federal law, if enforced, would be as effective as face-to-face sales in preventing access by minors to alcoholic beverages through mail-order delivery.

To complement federal regulations of interstate shipments of alcoholic beverages, states should enact regulations that explicitly proscribe unlicensed distribution or sale of alcoholic beverages obtained through lawful direct shipment. Of course, every state's liquor control laws already prohibit unlicensed retail sales of alcoholic beverages, but directing similar regulations at direct shippers and consumers receiving direct shipments would make the applicability of these laws to direct-shipping transactions explicit. If states deem simple prohibition of unlicensed distribution of alcoholic beverages obtained through direct shipment insufficient to protect their interests, limiting the legal quantity of alcoholic beverages that an individual may purchase outside of the state's three-tier distribution system, as several states have done, ${ }^{172}$ would likely survive dormant Commerce Clause scrutiny as a valid exercise of "core" powers. ${ }^{173}$ Such laws, while still discriminating against interstate commerce in that they limit consumer access to some out-of-state wines and limit market access by many out-of-state wine producers, should be defensible under the Twenty-first Amendment as the least discriminatory means of exercising core Twenty-first Amendment powers. Quantity limitations would permit state residents to purchase wines from out-of-state wineries whose products are not available through the state-regulated distribution system and would also serve the state's interest in ensuring that direct shipments would not foster illegal channels of distribution, would not

170. See 145 CONG. REC. S5345 (daily ed. May 14, 1999) (statement of Sen. Feinstein).

171. See id. (introducing Amendment No. 354 to the proposed Violent and Repeat Juvenile Offender Accountability and Rehabilitation Act of 1999).

172. See supra note 134 and accompanying text.

173. See supra Part IV. 
undermine state efforts to promote temperance, and would not increase access by minors to alcoholic beverages.

\section{CONCLUSION}

While absolute proscription of interstate commerce in alcoholic beverages that are not distributed through a state's three-tiered distribution system smacks of commercial protectionism, particularly in those states that permit alcoholic beverages manufactured in-state to be purchased and shipped to residents without passing through the three-tiered system, states do have legitimate concerns in preventing unrestricted distribution of alcoholic beverages and the right to exercise core powers conferred by the Twenty-first Amendment. Thus, as the Supreme Court has intimated in its modern Twenty-first Amendment jurisprudence, and lower federal courts have found explicitly in recent challenges to anti-direct-shipping laws, the states must find that level of regulation of commerce in alcoholic beverages where they are able to protect the core powers reserved to them by the Amendment while minimally imposing on interstate commerce. State legislation permitting direct shipment of alcoholic beverages in limited quantities combined with federal legislation regulating transportation and delivery of alcoholic beverages by common carriers will effectively balance federal interests in unrestricted interstate commerce and state interests in protecting the health and welfare of their citizens from the dangers of an unrestricted liquor trade. Only a complementary set of federal and state direct-shipment regulations such as these can pass constitutional scrutiny while permitting states to use their core powers under the Twenty-first Amendment. 